\title{
Telework, Hybrid Work and the United Nation's Sustainable Development Goals: Towards Policy Coherence
}

\author{
Magnus Moglia 1,*(D), John Hopkins ${ }^{2}$ and Anne Bardoel ${ }^{2}$ \\ 1 Centre for Urban Transitions, Swinburne University of Technology, Hawthorn, VIC 3122, Australia \\ 2 School of Business, Law and Entrepreneurship, Swinburne University of Technology, Hawthorn, VIC 3122, \\ Australia; jlhopkins@swin.edu.au (J.H.); abardoel@swin.edu.au (A.B.) \\ * Correspondence: mmoglia@swin.edu.au
}

check for updates

Citation: Moglia, M.; Hopkins, J.; Bardoel, A. Telework, Hybrid Work and the United Nation's Sustainable Development Goals: Towards Policy Coherence. Sustainability 2021, 13, 9222. https://doi.org/10.3390/ su13169222

Academic Editor: Hyo Sun Jung

Received: 31 July 2021

Accepted: 13 August 2021

Published: 17 August 2021

Publisher's Note: MDPI stays neutral with regard to jurisdictional claims in published maps and institutional affiliations.

Copyright: (c) 2021 by the authors. Licensee MDPI, Basel, Switzerland. This article is an open access article distributed under the terms and conditions of the Creative Commons Attribution (CC BY) license (https:// creativecommons.org/licenses/by/ $4.0 /)$.
Abstract: With increased participation in telework expected to continue, in the aftermath of COVID, it will be important to consider what long-term impact this practice could have on sustainability outcomes. This paper describes a scoping review and identifies connections between telework and sustainability outcomes from previous academic studies. These connections were categorised, and are discussed, based on their contributions to different United Nations Sustainable Development Goals. Most research was found to focus on countries classified as having a very high human development index status. The SWOT matrix technique was used to illustrate the strengths and weaknesses identified in the existing literature, and the threats and opportunities for future work. This aims to ensure policy coherence so that strategies to promote one outcome, such as economic productivity improvements, do not undermine another, such as improved health. Practical implications and research opportunities were identified across a range of SDG impact areas, including good health and well-being, gender equality, reduced inequality, climate mitigation, sustainable cities, and resilient communities. Overall, our impression is that increased rates of telework present an important opportunity to improve sustainability outcomes. However, it will be important that integrated and holistic policy is developed that mitigates key risks.

Keywords: telework; hybrid work; working from home; sustainability; UN sustainable development goals; SDG; policy coherence

\section{Introduction}

The disruption from the COVID-19 pandemic has been widespread, yet the world also simultaneously faces more serious challenges, with human-induced environmental change posing catastrophic risks to life on earth [1,2]. It is widely agreed in sustainability science that meeting human needs and environmental sustainability need to go hand in hand [3]. Consistent with this, all United Nations member states have signed up to bold and ambitious goals, to improve human welfare and environmental health across 17 sustainable development goals [4]:

- Goal 1. End poverty in all its forms everywhere;

- Goal 2. End hunger, achieve food security and improved nutrition and promote sustainable agriculture;

- Goal 3. Ensure healthy lives and promote well-being for all at all ages;

- Goal 4. Ensure inclusive and equitable quality education and promote lifelong learning opportunities for all;

- Goal 5. Achieve gender equality and empower all women and girls;

- Goal 6. Ensure availability and sustainable management of water and sanitation for all;

- Goal 7. Ensure access to affordable, reliable, sustainable and modern energy for all;

- Goal 8. Promote sustained, inclusive and sustainable economic growth, full and productive employment and decent work for all; 
- Goal 9. Build resilient infrastructure, promote inclusive and sustainable industrialisation and foster innovation;

- Goal 10. Reduce inequality within and among countries;

- Goal 11. Make cities and human settlements inclusive, safe, resilient and sustainable;

- Goal 12. Ensure sustainable consumption and production patterns;

- Goal 13. Take urgent action to combat climate change and its impacts;

- Goal 14. Conserve and sustainably use the oceans, seas and marine resources for sustainable development;

- Goal 15. Protect, restore and promote sustainable use of terrestrial ecosystems, sustainably manage forests, combat desertification, and halt and reverse land degradation and halt biodiversity loss;

- Goal 16. Promote peaceful and inclusive societies for sustainable development, provide access to justice for all and build effective, accountable and inclusive institutions at all levels;

- Goal 17. Strengthen the means of implementation and revitalise the Global Partnership for Sustainable Development.

The COVID-19 pandemic has already led to improvements in certain sustainability outcomes, including reduced greenhouse gas emissions [5] and improved air quality $[6,7]$. Telework has been proposed as an integral part of a green recovery after the pandemic [8], based, in part, on the fact that telework has made an important transition during the COVID-19 pandemic, from being spearheaded by a small number of early adopters to now seeing widespread and mainstream adoption among workers [9-13]. Many institutions, such as the OECD, have argued that telework and hybrid work practices need to be more widely integrated into the business process and government planning [14]. This creates opportunities for helping to achieve sustainable development goals [8-13]. Hybrid work arrangements, which combine the benefits of both telework and office work, are now widely expected to be the dominant model for the future of work [15]. The question is whether telework and hybrid work practices can provide a positive tipping point towards a more sustainable future $[8,16]$.

The COVID-19 pandemic resulted in what has been called "the world's biggest workfrom-home experiment" [17], as governments and businesses around the world were suddenly forced into the adoption and integration of teleworking practices as a means of business continuity in the face of strict pandemic lockdown restrictions. It has also been argued that the widespread adoption of telework can form part of strategies with considerable potential to help communities live healthier and more productive lives, while simultaneously improving the chances to live within planetary boundaries [18]. Telework practices have also been known to appear in scenarios for future societies, with wide societal impacts $[19,20]$. More recently, a significant focus has been placed on the fact that teleworking helps to reduce overall travel demand and road congestion, while also increasing active forms of transport, such as walking and cycling [21].

Numerous studies have now linked telework with impacts on sustainability. However, we argue that strategies that leverage telework to achieve sustainability outcomes must be considered in a comprehensive and integrated manner, across all relevant outcomes. Therefore, this paper aims to review the key themes in the academic literature that describe any association between telework and the various dimensions of sustainability, as defined by the Sustainable Development Goals (SDGs).

This article describes a scoping review of the current academic literature, which aims to address the research question:

"RQ-How has the link between telework and sustainability outcomes been explored in the academic literature, and what does it represent in terms of risks or opportunities for achieving sustainability goals?" 


\subsection{The Obvious Impacts of Telework during the COVID-19 Pandemic}

During the pandemic, many factories, offices, and shops were forced to close, and the movement of global freight was severely impacted [22], as cities around the world quickly introduced emergency measures to control the spread of the disease [23-25]. With many people unable to travel to their usual places of work, for example, offices in cities, a sudden shift towards "work from home" arrangements occurred [26]. Although this was a challenging time for many reasons, numerous benefits emerged, particularly from a sustainability perspective, due to the resulting sudden and significant reduction in commuter numbers.

Demand for roads, public transport, and commercial flights plummeted almost overnight [27]. As cities went into lockdown, streets suddenly became empty and trafficrelated emissions, particularly carbon dioxide $\left(\mathrm{CO}_{2}\right)$ and nitrogen dioxide $\left(\mathrm{NO}_{2}\right)$, dropped dramatically in many locations [28]. $\mathrm{CO}_{2}$ is a greenhouse gas (GHG) that is a significant contributor to global warming, and $\mathrm{NO}_{2}$ is associated with atmospheric reactions, which produce ozone and fine particulates linked with increases in human respiratory tract infections that can lead to death [29].

In November 2020, NASA used computer-generated simulations to model the recorded reductions in air pollution, compared with what a "COVID-free 2020" would have generated. It concluded that the pandemic restrictions resulted in a global reduction in nitrogen dioxide $\left(\mathrm{NO}_{2}\right)$ concentrations of nearly 20 percent [30]. Similarly, Venter et al. [31] were able to leverage mobility data from Google and Apple to establish a link between the decline in global vehicle transportation usage and reductions in ambient $\mathrm{NO}_{2}$ levels.

\subsection{Telework Maturing as an Innovation}

Although the widespread adoption of telework was initially a short-term phenomenon and a reaction to lockdown conditions, many believe that the practice will now become entrenched. This is due, in large part, to a growing recognition of private and public benefits. For individuals, telework presents an opportunity for improving health and wellbeing, in addition to work-life balance, through the reduction of non-essential journeys. For the wider economy, telework, or some form of working from home, has proven to be a promising strategy for improving economic productivity and business profitability.

\subsection{Private Benefits}

Despite the challenging circumstances, many workers reported improvements in health and work-life balance while working from home [10,32]. Links between telework and lower instances of heart attacks have even been identified by hospitals in Finland and the USA [33]. Many teleworkers are now noting a preference for working from home; in turn, this has impacted decision making regarding where people want to live over the longer term. If workers no longer need to commute to a city office 5 days per week, perhaps they can live further away, in a larger home in a more affordable area? For example, recent US research analysed real estate data to understand the impact COVID-19 had on housing demand. It identified a pronounced shift away from high population density areas and attributed this reduction in demand to "the diminished need of living close to telework-compatible jobs and the declining value of access to consumption amenities" [34].

\subsection{Economic Benefits for Business}

In many cases, overall productivity did not decline, but rather it has been argued that telework can in fact help improve productivity [14]. Many businesses instead have seen significant economic gains from allowing their staff to work from home, and some seized the opportunity to reduce costs by minimising expenditures on office space $[32,35,36]$. These benefits are generally thought to be the greatest when part of a hybrid work model, which combines a mix of working from home/remotely at least $25 \%$ of the time, with working from a traditional workplace such as an office [37]. 


\subsection{Telework Is Here to Stay}

For this paper, we assume that the trend towards increased telework will continue, albeit likely in a non-linear fashion that will first include some level of "bounce back" to somewhere below pre-COVID-19 levels, followed by an ongoing acceleration towards more telework practices in the future. This assumption is based on an understanding of behavioural change through a complex process of innovation diffusion that involves multiple actor types, similar to that described for other types of behavioural changes [38,39]; consideration of telework as a social practice that can be described through the theory of planned behaviour [40]; and with an understanding of the following:

- The current move to telework is accelerating an existing trend that had been gathering pace over the past several decades [41-48].

- Key factors that have thus far influenced the prevalence of telework are associated with previously limited management and staff confidence of being able to productively work from home, employers' limited adoption of IT systems and policy frameworks to support telework, and a previous lack of awareness of the benefits of working from home $[10,11]$. Having a positive experience of working from home is the strongest predictor of wanting to work from home in the future [9,49], and the dominant experience for most of those who have now worked from home is that it has indeed been a very positive experience [9,49-51].

- As many workers and employers have overcome previous negative perceptions and barriers to telework [50,51], with many employers now encouraging their staff to continue working from home [52], this means that from a behavioural change perspective, we can expect many more people to want to work from home, and many more to have employers that allow them to do so. This is reinforced by many surveys that indicate large proportions of working populations embracing some level of telework as their preferred mode $[9,10,50,52,53]$.

\section{Materials and Methods}

\subsection{Review Approach}

The methodology adopted for this investigation was the scoping review, which is a commonly used method for mapping existing academic literature from a particular field of interest, to better understand the extent, range, and nature of the research activity that has been previously conducted $[53,54]$. This type of review is regarded as being particularly effective when the subject area is heterogeneous in nature $[55,56]$, as is the case with the sustainability outcomes of telework.

The scoping review method was selected as being the most appropriate methodology for this research because the purpose of this particular type of review is to present an overview of a diverse range of literature [54]. This is in contrast to a narrowly-focused set of literature based around a more specific research question, for which a systematic literature review (SLR) would be more appropriate $[53,57]$. Drawing on an adaptation of the process proposed by Arksey and O'Malley [54], our method includes the following steps:

1. Identify research question (see Section 1);

2. Identify relevant studies (see Table 1);

3. Study selection (see Table 1);

4. Identify whether a chosen article makes a contribution that connects telework with any of the SDGs (see Table 1);

5. Charting the data (see Section 3.1);

6. Collating, summarising, and reporting (see Section 3.2);

7. Expanding on the practical implications (see Sections 4 and 5). 
Table 1. Articles for SLR, by SDG area.

\begin{tabular}{|c|c|c|c|c|}
\hline SDG \# * & $\mathrm{n}$ & Included Articles & $\begin{array}{l}\text { Articles Added via } \\
\text { Snowballing }\end{array}$ & $\begin{array}{c}\text { Excluded (Outside of Scope, } \\
\text { Inaccessible or Book Chapter } \\
\text { etc.) }\end{array}$ \\
\hline 3 & 16 & \multirow{10}{*}{$\begin{array}{c}{[13,58-73]} \\
{[82-84]} \\
{[12,86-89]} \\
{[62-64,70,79,93-103]} \\
{[13,86,88,102,114-123]} \\
{[132]} \\
{[49,133-146]} \\
{[46,123,137,160,162-164]} \\
{[42,45,46,133,135,137,162,167-} \\
176]\end{array}$} & {$[6,7,74-79]$} & {$[80,81]$} \\
\hline 4 & 3 & & \multirow{5}{*}{ [90] } & [85] \\
\hline 5 & 5 & & & {$[91,92]$} \\
\hline 8 & 14 & & & [104-113] \\
\hline 9 & 14 & & & [124-131] \\
\hline 10 & 1 & & & \\
\hline 11 & 15 & & [147-153] & \multirow[t]{3}{*}{ [154-161] } \\
\hline 12 & 3 & & {$[165,166]$} & \\
\hline 13 & 15 & & [177] & \\
\hline N/A & & & & {$[126,178-183]$} \\
\hline
\end{tabular}

$\left({ }^{*}\right)$ Note: SDG \# refers to the relevant Sustainable Development Goal as per United Nations [4].

To identify relevant studies that in some ways explore how telework may influence sustainability outcomes, the following search terms were used:

("telework" OR "work from home" OR "flexible work" OR "remote work") AND "sustainab *"

Scopus was used as the database for accessing high-quality peer-reviewed articles, with the following delimiters employed to specify the boundary of the search:

- Only include articles published in English;

- Include articles from all years;

- Journal articles and conference papers (but no book chapters, or working papers, etc.);

- Articles in press, and those which have been accepted for publication but not yet assigned to a journal volume/issue, were also included to capture the most up-to-date research in this area;

- $\quad$ Any discipline area;

- No articles were excluded based on the quality ranking of the journal.

The searches were conducted on 9 June 2021 and, after removing any duplicates, resulted in an initial sample of $\mathrm{n}=116$ articles for analysis. At this stage, the authors independently reviewed the titles and abstracts from all 116 papers, to further assess and screen for their appropriateness for the study, and to decide which SDG(s) they believed each paper aligned best with, based on a judgment of whether articles clearly contribute to an understanding of how telework may impact SDG targets. In most cases, this judgment was clear, because excluded articles either did not explore teleworking in a substantive manner or covered topics that relate to sectors or issues that are unrelated to SDGs.

At this stage, articles were included if they appeared to explore, at least incidentally, both the topic of telework and any of the sustainability issues covered by the SDGs.

The authors then reconvened to discuss their results as a group, and make decisions on any discrepancies that arose. This process resulted in a set of $n=97$ papers, featuring potential links between telework and 9 different SDG areas, with 19 articles being excluded from the analysis because they were no longer deemed appropriate for this investigation.

The articles were then divided between the three authors, based upon their discipline expertise, for full-text analysis. At this stage, after a full reading of the articles as part of the material selection process, an additional 17 articles were excluded from the sample, and 6 were reclassified as having closer alignment to different SDGs than originally thought.

After full-text analysis of these papers, backward snowballing was then employed, which is a process that uses the reference lists from the original articles to help identify additional articles that were not captured in the original search. Based on this process, a further 19 articles were captured, and these were reviewed in full, and added to the final sample. The inclusion of snowballed articles was based on (a) only being able to include a limited sample due to time and space constraints, and (b) the identified snowballed articles 
providing insights that were relevant for the core arguments, context, and/or evidence provided by the articles that we reviewed.

This resulted in a final sample of 99 papers, as illustrated in Table 1. It is noted that while the final sample of papers was $n=99$, some of the papers were found to discuss multiple SDGs and appear in more than one category.

\subsection{SWOT Analysis}

SWOT analysis is a strategic management tool, originating in the 1950s, which was designed to assist in the identification of Strengths, Weaknesses, Opportunities, and Threats in an organisation, plan, project, person or activity $[184,185]$. It commonly involves the development of a $2 \times 2$ "SWOT Matrix", that helps to visualise internal strengths and weaknesses, in addition to external opportunities and threats [186].

Here, the focus of the SWOT analysis was "the practice of telework" and its impact on SDGs. The manner in which factors were categorised as strengths (S), weaknesses (W), opportunities $(\mathrm{O})$ or threats $(\mathrm{T})$, is based on the following principles:

- Strength: something that gives telework an advantage over other ways of working, such as a mechanism by which telework helps to achieve SDGs and generates value for individuals, organisations, the environment, and/or society.

- Weakness: the opposite of strength, and something that makes telework less likely to help achieve SDGs and that detracts from the value generated by the practice.

- Opportunity: factors or strategies to be considered that can help increase the chances for telework to help achieve SDGs and generate private or social value, i.e., to either promote strengths, limit weaknesses, or reduce risk.

- Threats: issues that pose risks that could potentially lead to reduced value and an undermining of efforts to achieve SDGs. Threats are risks that require mitigation.

The identification of factors in the SWOT matrix was based on an initial synthesis of the insights from the literature, followed by a discussion between the authors, and finally a consensus agreement on the choices that were made.

For this investigation, the researchers adopted the SWOT technique for identifying and categorising the strengths, weaknesses, opportunities, and threats related to SDGs due to the practice of telework, as documented in the literature. It is hoped this process will lead to the recognition of weaknesses and gaps in the current body of academic knowledge, and the identification of future research opportunities.

\section{Results and Discussion}

\subsection{Descriptive Analysis}

Articles exploring links between telework and sustainability were found to first emerge in 2000, and grow slowly in number over the following two decades, until a steep and sudden increase was observed in recent years. In 2019 only $n=6$ articles were found to discuss the presence of these links, but this rose to $n=21$ in 2020 and is projected to reach $n$ $=39$ by the end of 2021, probably due to the increased interest in the field of telework as a result of COVID-19, starting in early 2020 (see Figure 1).

A breakdown of articles in terms of their geographic focus, based on the location of the first authors' institutes, was analysed. A share of $86 \%$ of the articles were found to come from countries with a very high human development index status, $10 \%$ from countries with a high human development index, and only $4 \%$ come from countries with a low or medium human development index [187]. A share of $37 \%$ of articles originated in the European Union, and $18 \%$ of articles originated from the United States. Beyond this, $16 \%$ of articles originated in Asia, of which 6\% originated from East Asia. This shows a considerable bias towards Western high-income countries (see Table 2 and Figure 2). 


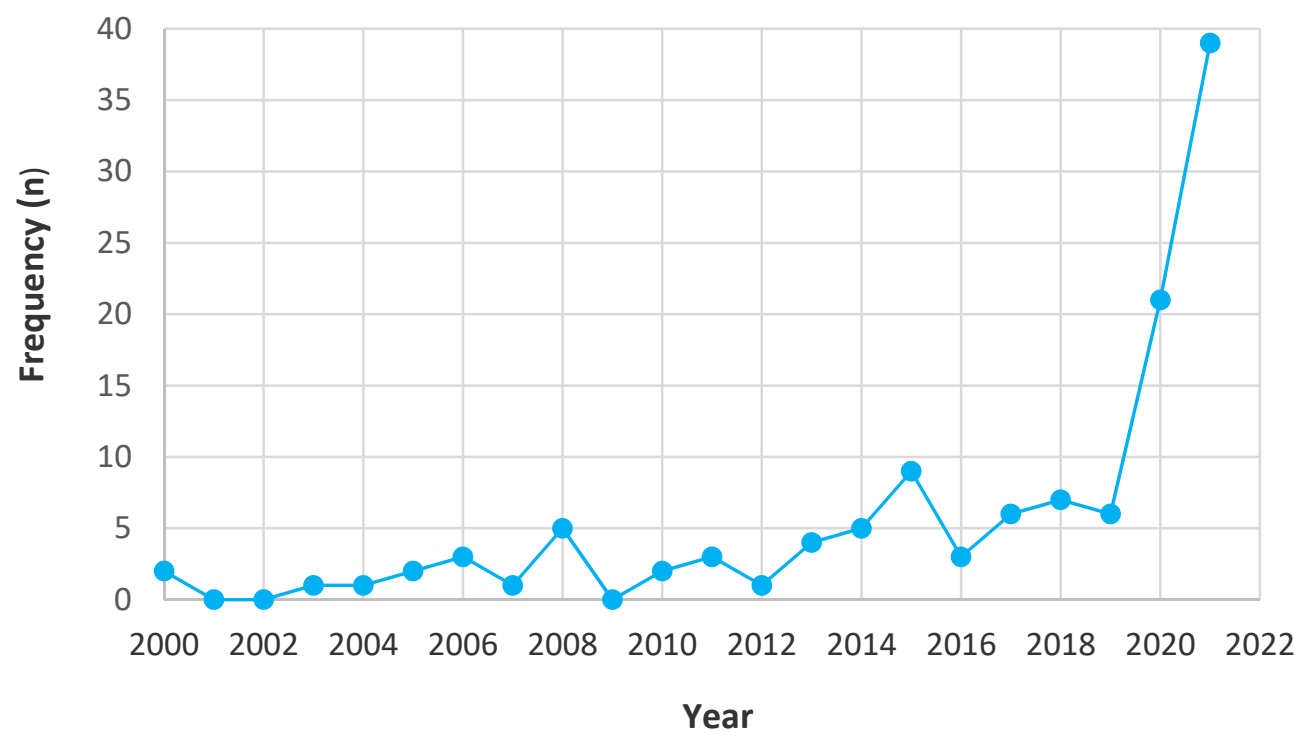

Figure 1. Articles linking telework and sustainability over time (2000-2021). Note that the number of papers for 2021 has been extrapolated based on current papers published at an equal rate for the remainder of the year, i.e., this does not adequately consider exponential growth and does not fully consider early or delayed publication of papers.

Table 2. Articles featuring links between telework and sustainability, by country and UN Regional Group.

\begin{tabular}{|c|c|c|c|c|c|}
\hline Country & $\mathbf{n}$ & UN Region & Country & $\mathbf{n}$ & UN Region \\
\hline United States & 18 & $\begin{array}{c}\text { Europe and Northern } \\
\text { America }\end{array}$ & Ireland & 2 & $\begin{array}{c}\text { Europe and Northern } \\
\text { America }\end{array}$ \\
\hline Australia & 11 & $\begin{array}{c}\text { Australia and New } \\
\text { Zealand }\end{array}$ & Japan & 2 & $\begin{array}{l}\text { Eastern and } \\
\text { South-Eastern Asia }\end{array}$ \\
\hline United Kingdom & 7 & $\begin{array}{c}\text { Europe and Northern } \\
\text { America }\end{array}$ & Romania & 2 & $\begin{array}{c}\text { Europe and Northern } \\
\text { America }\end{array}$ \\
\hline Netherlands & 5 & $\begin{array}{c}\text { Europe and Northern } \\
\text { America }\end{array}$ & Turkey & 2 & $\begin{array}{l}\text { North Africa and } \\
\text { Western Asia }\end{array}$ \\
\hline Canada & 5 & $\begin{array}{c}\text { Europe and Northern } \\
\text { America }\end{array}$ & Cyprus & 1 & $\begin{array}{c}\text { Europe and Northern } \\
\text { America }\end{array}$ \\
\hline Sweden & 5 & $\begin{array}{c}\text { Europe and Northern } \\
\text { America }\end{array}$ & Colombia & 1 & $\begin{array}{c}\text { Latin America and the } \\
\text { Caribbean }\end{array}$ \\
\hline Spain & 4 & $\begin{array}{c}\text { Europe and Northern } \\
\text { America }\end{array}$ & Nigeria & 1 & Sub-Saharan Africa \\
\hline Italy & 4 & $\begin{array}{c}\text { Europe and Northern } \\
\text { America }\end{array}$ & Norway & 1 & $\begin{array}{c}\text { Europe and Northern } \\
\text { America }\end{array}$ \\
\hline India & 3 & $\begin{array}{l}\text { Central and Southern } \\
\text { Asian }\end{array}$ & Austria & 1 & $\begin{array}{c}\text { Europe and Northern } \\
\text { America }\end{array}$ \\
\hline Finland & 3 & $\begin{array}{c}\text { Europe and Northern } \\
\text { America }\end{array}$ & Poland & 1 & $\begin{array}{c}\text { Europe and Northern } \\
\text { America }\end{array}$ \\
\hline Germany & 3 & $\begin{array}{c}\text { Europe and Northern } \\
\text { America }\end{array}$ & Singapore & 1 & $\begin{array}{l}\text { Eastern and } \\
\text { South-Eastern Asia }\end{array}$ \\
\hline Ukraine & 2 & $\begin{array}{c}\text { Europe and Northern } \\
\text { America }\end{array}$ & Taiwan & 1 & $\begin{array}{c}\text { Eastern and } \\
\text { South-Eastern Asia }\end{array}$ \\
\hline Belgium & 2 & $\begin{array}{c}\text { Europe and Northern } \\
\text { America }\end{array}$ & South Korea & 1 & $\begin{array}{c}\text { Eastern and } \\
\text { South-Eastern Asia }\end{array}$ \\
\hline China & 2 & $\begin{array}{c}\text { Eastern and } \\
\text { South-Eastern Asia }\end{array}$ & Vietnam & 1 & $\begin{array}{c}\text { Eastern and } \\
\text { South-Eastern Asia }\end{array}$ \\
\hline
\end{tabular}




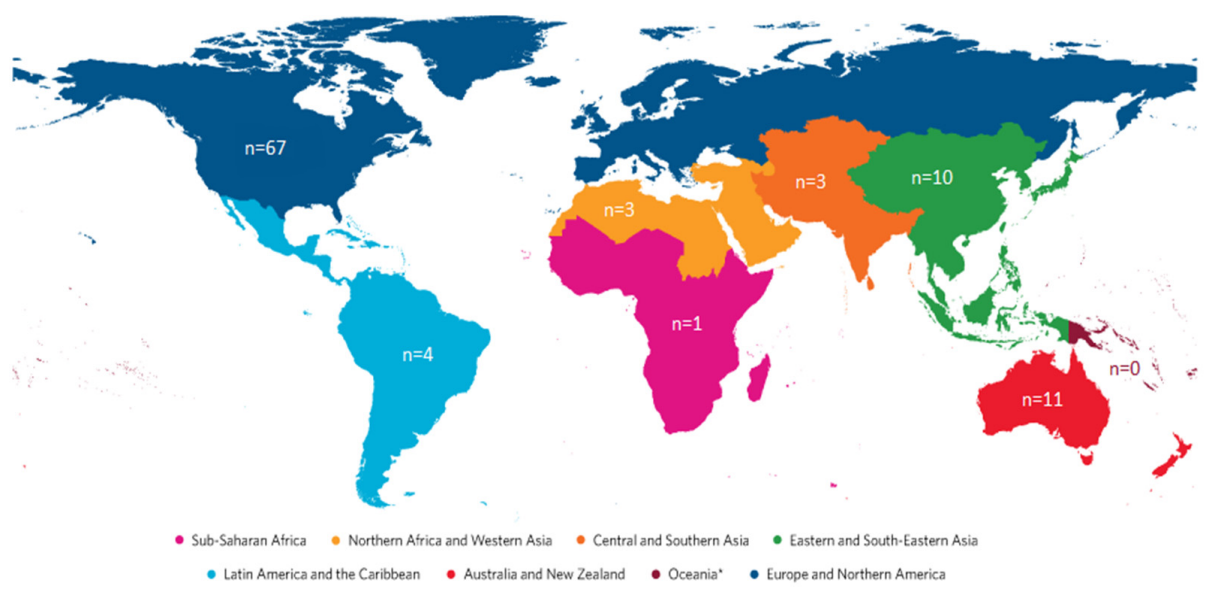

Figure 2. Telework and sustainability literature by UN Regional Groupings ( $\mathrm{n}=99)$.

The key journal for research in this field, that appeared in the greatest number of results using the search terms described, was found to be Sustainability, which featured fifteen $(n=15)$ articles discussing possible links between telework and sustainability. The title appearing the second most times in the sample was Transport Policy $(n=4)$, followed by European Journal of Transport and Infrastructure Research, Human Relations, Indian Journal of Science and Technology, and Transportation Research Part A: Policy and Practice $($ all $n=2)$. No other journal titles appeared more than once in the sample (see Figure 3).

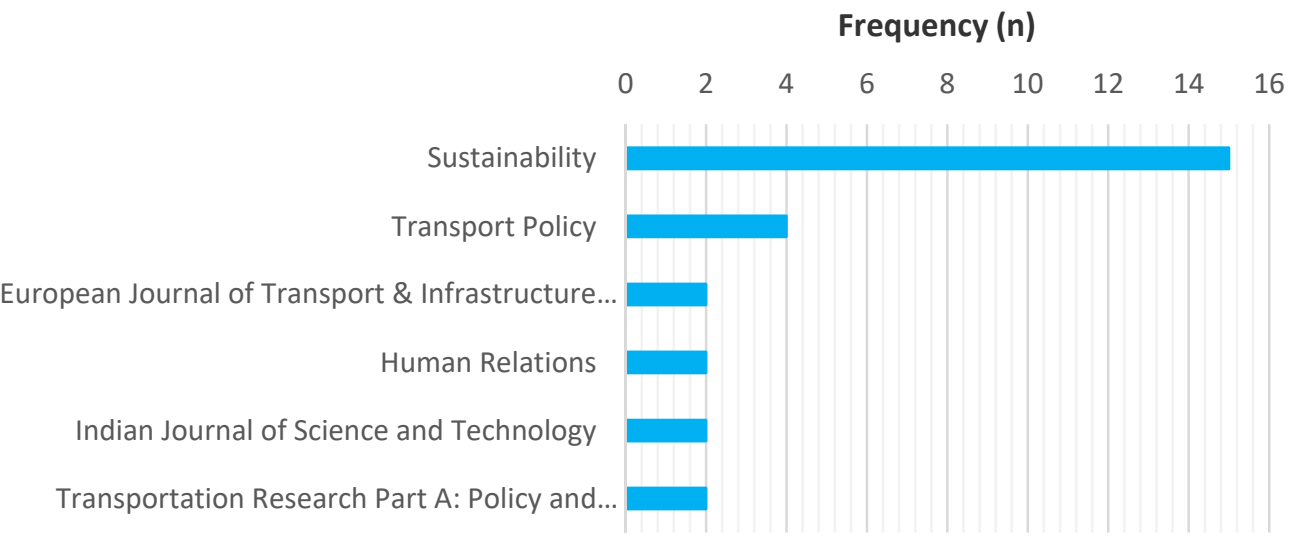

Figure 3. Key journals identified in the review.

To illustrate the diversity in the focus of the journals appearing in the sample, they ranged from the likes of the Journal of Transport Geography and Sustainability Accounting $\&$ Reporting to Infectious Diseases of Poverty and Midwifery. This variety underlines the multidisciplinary nature, and extensive reach, of the subject matter.

\subsection{Range of SDGs Linked to Telework}

Links between telework and nine $(n=9)$ different SDG areas were identified in the sample of academic literature exploring connections between telework and sustainability, with SDG9 (Build resilient infrastructure, promote inclusive and sustainable industrialisation and foster innovation) $(\mathrm{n}=18)$, SDG3 (Good health and well-being) $(\mathrm{n}=16)$, SDG8 (Promote sustained, inclusive and sustainable economic growth, full and productive employment and decent work for all) $(\mathrm{n}=16)$, SDG11 (Sustainable cities and communities) (n $=16)$, and SDG13 (Climate action) $(\mathrm{n}=16)$ featuring most prominently (see Figure 4$)$. 


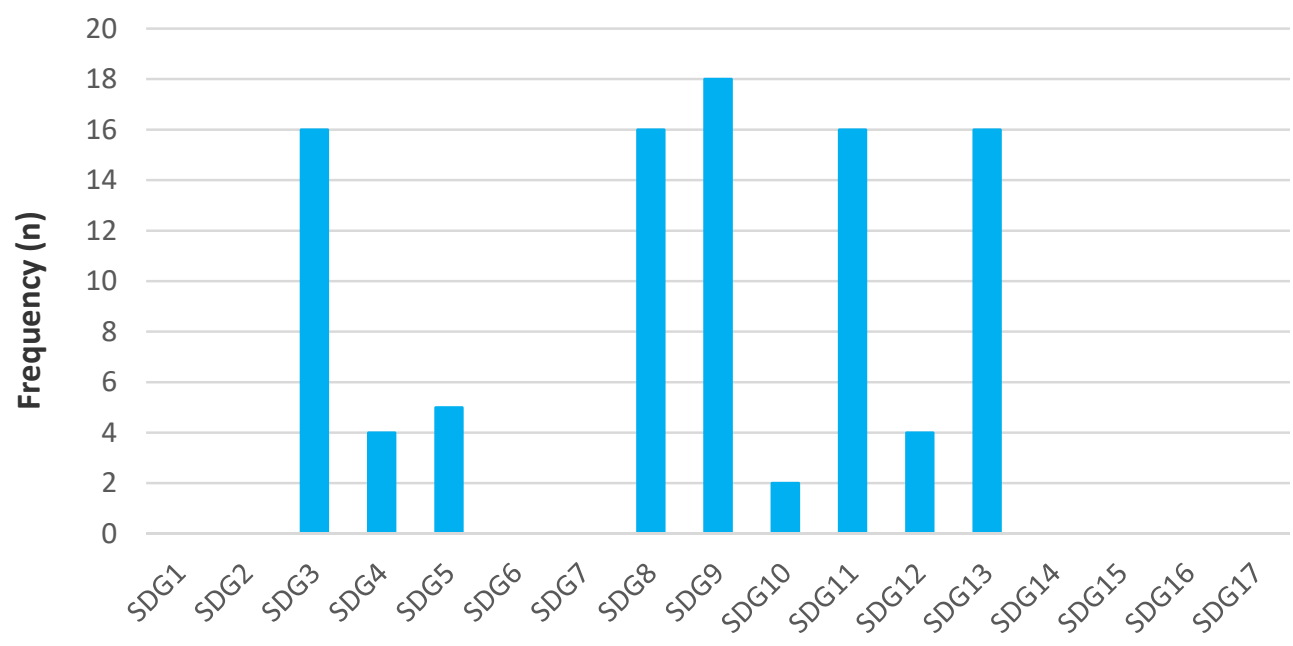

Figure 4. The number of articles in the search mapped to each of the SDGs.

The links between telework, and these key nine SDG areas, now forms the basis of a detailed discussion.

\subsection{Links between Telework and the UN Sustainable Development Goals}

This investigation utilises the UN's list of 17 SDGs as a framework for classifying the connection between telework and sustainability outcomes that are present in the current body of academic literature. We now provide a summary of the key insights from the sample concerning how telework is seen as supporting sustainability and promoting specific UN sustainable development goals (SDG).

\subsubsection{SDG 3: Good Health and Well-being}

Relevant targets for this goal [4] are shown in Text Box 1.

Box 1. SDG 3 targets relevant to telework.

3.3. By 2030, end the epidemics of AIDS, tuberculosis, malaria and neglected tropical diseases and combat hepatitis, water-borne diseases and other communicable diseases

3.4. By 2030, reduce by one third premature mortality from non-communicable diseases through prevention and treatment and promote mental health and well-being

3.5. Strengthen the prevention and treatment of substance abuse, including narcotic drug abuse and harmful use of alcohol

3.6. By 2020, halve the number of global deaths and injuries from road traffic accidents

3.9. By 2030, substantially reduce the number of deaths and illnesses from hazardous chemicals and air, water and soil pollution and contamination.

Communicable diseases (3.3): Telework was most obviously a matter of health during the COVID-19 pandemic when it served to protect employees from disease. BelzuneguiEraso and Erro-Garces [13] note this protective function and also suggest that telework may protect health and productivity during severe disasters, such as earthquakes or the 9/11 attacks.

Non-communicable diseases (3.4): Less directly, Hoffman et al. [58] addressed telework during COVID-19 lockdowns for employees in radiation oncology, radiation physics, and experimental radiation oncology, and found significant reductions in self-reported burnout among teleworking employees. Drywień et al. [73] found that, among a group of Polish women, unhealthy dietary habits and high amounts of screen time during COVID-19 lockdown significantly led to unhealthy weight gains and increased risks of lifestyle diseases. Importantly, however, telework is strongly linked with work-related flexibility [72], and there is evidence to indicate that flexible work arrangements may broadly, particularly 
for married, professional women, increase satisfaction and reduce burnout [59]. Relatedly, presenteeism, or showing up in the workplace while ill, is often viewed as antithetical to telework, but Karanika-Murray and Biron [60] note that many benefits of presenteeism, particularly in terms of social support, may only be accessed through telecommuting when a contagious disease or mobility hindrance is involved. Their work implicitly suggests that telework during the COVID-19 lockdowns may have provided valuable social supports that were not available to employees who simply could not perform their jobs. Relatedly, telework as part of broader flexible work policies may facilitate return to work after strokes [61]. Telework that involves substantial job autonomy can improve work-life balance and thereby reduce the incidence of burnout [62]. The issues of job autonomy and control, being central to the promotion of work-life balance by telework, also appear in other studies $[63,64]$. Schellhammer et al. [65] argue that telework that provides job autonomy and control can be used by employees for primary preventive health care, such as ensuring sufficient sleep or breaks, or setting time aside when emails are not read. They argue that these coping strategies can reduce stress and burnout.

On the positive side, telework as part of efforts to create walkable, sustainable communities may be associated with increased levels of exercise in terms of walking [66]. Further, some evidence suggests telework frees up time for adult children to care for ageing parents [67]. Additionally, COVID-19 lockdowns initially led to substantial mobility from dense, urban areas to rural, tourist areas [74], and Vesala and Tuomivaara [68] found in an experiment that telework in rural areas reduced subjective time pressures and interruptions, and was associated with lower levels of exhaustion and higher levels of job satisfaction, suggesting such mobility may have positive health effects.

However, it is also possible for telework to promote sedentary behaviours that have adverse health effects [69], and isolation that may have adverse effects on mental health [70]. Further, telework may create subjective time pressure, which can particularly affect women and parents [71].

Substance abuse (3.5): None of the chosen articles explored such a link.

Traffic accidents (3.6): Based on the estimated reduction in traffic and congestion, Alonso and colleagues [171] in the context of Madrid, Spain, estimated several thousand fewer traffic accidents over several decades as a likely result of teleworking practices. Furthermore, beyond rudimentary statements relating to the reduction in traffic accidents, such as statements online that state telecommuting can save thousands of lives [188], there appears to be a lack of studies that confirm a reduction in traffic accidents. Nonetheless, telework would appear very likely to play a key role in reducing global deaths and injuries from traffic accidents.

Deaths from air pollution (3.9): Globally, 9 out of 10 people breathe air that exceeds WHO pollution guidelines and, as a result, 4.2 million deaths occur each year as a result of exposure to ambient air pollution [189]. Several studies have shown that when telework reduces traffic and congestion, it also has considerable benefits in terms of improved air quality $[6,7,75-78]$. However, some of these results are likely conflated by the current lockdowns, which have made the telework scenario more extreme. Nonetheless, there are good indications that the number of deaths and injuries arising from poor air quality may be considerably reduced through higher adoption of telework.

\subsubsection{SDG 4: Quality Education}

Themes aligning with SDG 4 were prominent in three $(n=3)$ articles included in the literature sample. Relevant targets for SDG4 [4] are shown in Text Box 2. 
Box 2. SDG 4 targets relevant to telework.

4.3. By 2030, ensure equal access for all women and men to affordable and quality technical, vocational and tertiary education, including university

4.5. By 2030, eliminate gender disparities in education and ensure equal access to all levels of education and vocational training for the vulnerable, including persons with disabilities, indigenous peoples and children in vulnerable situations

Equal access to ongoing and employment relevant education (4.3): The findings from a 2021 academic literature review, conducted to forecast the impact of the sudden increase in telework due to COVID-19 on the future working life, suggested that one area lacking from previous studies was the relationship between telework and lifelong learning [82]. The authors felt this was important, because "research about telework and lifelong learning has the potential to contribute to sustainable working life in terms of providing more flexible arrangements for employees and to support the lifelong learning that takes place in contexts such as the office, home, online meetings, and virtual reality" [82].

Accessible education for all groups (4.5): Online education is an alternative for providing widespread access to education for all types of groups. Kizilcec et al. [85] discovered that the recent uptake in telework, along with large-scale work retrenchment and the expansion of home schooling, gave rise to a significant surge in demand for online learning during COVID-19. Their investigation sought to understand whether this move to online learning could be leveraged to address long-term US workforce skills gaps, equitably and sustainably, and concluded that "these online platforms can provide an accessible and inclusive environment to learn new skills" [85]. Importantly, Dekenberger, Way, and Pearce [83] investigated how telework, along with remote training and education, can be combined to offer skilled employment opportunities to isolated communities. They concluded that the Internet has opened up many new telework and education opportunities to people choosing to remain in remote communities for family, religious, philosophical, or other reasons, and has the potential to help these people "out of poverty, reduce inequality overall, and provide those communities with viable means of employment security, now, and in the future" [83].

\subsubsection{SDG 5: Gender Equality}

The aim of SDG 5 is to advance commitments of gender equality. Relevant targets for SDG 5 [4] are shown in Text Box 3.

Box 3. SDG 5 targets relevant to telework.

5.B. Enhance the use of enabling technology, in particular information and communications technology, to promote the empowerment of women

5.5. Ensure women's full and effective participation and equal opportunities for leadership at all levels of decision-making in political, economic and public life

Use technology to promote the empowerment of women (5.B): Telework has the potential to promote increased diversity and social sustainability in terms of employees' ability to access flexible work arrangements. This theme was discussed in both Chitrao's [86] and Blake et al.'s [87] papers. Each paper highlighted the contribution to work-life integration for women of being able to access telework arrangements. Blake et al. also highlighted that flexible work arrangements such as telework are often "gendered" because more women than men are more likely to access flexible work arrangements. This often leads to hypervisibility, which can lead to conflict between motherhood and career expectations. Moreover, the study by Nguyen and Armoogum [12] is one of the first studies that provide a gender-based understanding of factors affecting the perception and the preference for WFH during the era of COVID-19 in a developing country (i.e., Vietnam). More women 
than men (56\% versus $45 \%$ ) reported having a positive perception of WFH when social distancing was enforced because of the pandemic. Exploring the field of flexible careers, and the impact institutions have on individuals' career decisions across their working lives, Tomlinson et al. [88] discussed the role of telework for helping women sustain employment, including following maternity, citing the work of Chung and Van der Horst [90].

Women's full and effective participation and equal opportunities for senior careers (5.5): Fathima and colleagues [89] undertook a multicentric cross-sectional study that gathered data from all SDG regions across the world about the challenges and coping strategies faced by female scientists. The researchers found several intrinsic (personal) and extrinsic (institutional) factors that are important for improving female scientists' well-being and productivity. Support from the workplace was the third most commonly employed coping strategy by female scientists in the study. Relevant to our discussion is that the scientists identified flexible work arrangements, such as being able to work from home and telework, as an important human resource change that would enable them to reconcile their home and work responsibilities. Ling and Leow [92] reported on a study of female construction graduates in Singapore and concluded that women in this traditionally male profession would be encouraged to stay if they were provided with flexible work schedules and opportunities to work at home so they could combine their work and home roles more effectively. Despite the popularity of FWAs, such as working from home (teleworking and telecommuting), these policies were found to be rare in Singapore in 2010. The Singapore Labour Force Survey found that, although women constitute $42 \%$ of the local labour force, only $15 \%$ in the construction sector are women, and of those women who graduate in construction, 33\% leave the industry. Interestingly, women considered home-based work could be a solution post-COVID-19 to relieve the burden that existed prior to COVID-19 and increased during the COVID-19 pandemic. It was seen as a potential strategy to help balance work and family duties, such as caring for children and family members. The women surveyed identified benefits of teleworking, including having flexible working time, avoiding long commute distances, and reducing exposure to pollution. Males, by contrast, were less likely to favour home-based work because in Vietnamese culture the breadwinner norm for men is strong and so they tended to report higher levels of pleasure derived by being at work. This study highlights that it is important for governments to consider the potential gender inequality effects of telework on the lives of citizens, especially female citizens, in developing countries.

\subsubsection{SDG 8: Decent Work and Economic Growth}

Telework can support workers' access to full and productive employment. Relevant targets for SDG8 [4] are shown in Text Box 4.

Box 4. SDG 8 targets relevant to telework.

8.5. By 2030, achieve full and productive employment and decent work for all women and men, including for young people and persons with disabilities, and equal pay for work of equal value. 8.8. Protect labour rights and promote safe and secure working environments for all workers, including migrant workers, in particular women migrants, and those in precarious employment.

Full and productive and full employment for all (8.5): Dima et al. [62] find that telework associated with substantial job autonomy and work-life balance may generate enhanced economic circumstances, including greater professional opportunities for young mothers, and reduced unemployment in rural areas. Furthermore, telework among older employees may help to respond to problems associated with an ageing population in many developed nations.

Population ageing has two problematic economic effects, i.e., shrinkage of the taxpaying labour force, and growth of the elderly in need of caregiving resources. Research in Singapore found that many older individuals who had retired would likely return 
if employment involving part-time/flexible work in locations close to the home was available [93], and research in the US suggests that older employees value flexible work arrangements more than their younger counterparts [64]. Telework could support these two conditions, particularly for occupations where results are measurable, and hence make developed economies more sustainable. Angeloni and Borgonovi [79] note that older employees may extend retirement age if, among other job characteristics, they are provided opportunities for interaction and social involvement. More broadly, research suggests that flexible work arrangements may play a role in extending the retirement age [93,94]. Telework may therefore expand opportunities for continued work as workers age, not only in terms of flexible work arrangements, but also as a tool for continued social interactions for individuals who become mobility impaired. By comparison, in-person work may better facilitate social interactions, undercutting the case for telework among older workers.

Furthermore, it is possible that sustainable employment for employees with various disabilities, such as those associated with multiple sclerosis [95], could be facilitated by telework. The converse of this relationship is that caregivers of family members often maintain employment by engaging in flexible work arrangements [96] and generally value flexible work arrangements [64].

Promote safe and secure working environments for all workers (8.8): Telework might directly facilitate family caregiving in tandem with employment. Galvez et al. [63] argue that organisations supportive of telework in the sense of setting objective goals, and providing job autonomy and control, support sustainable jobs and communities generally. Taking this approach further, Reed et al. [70] argue that telework implementation should involve all stakeholders in designing the specific policies, timing, and performance measures. In the absence of such involvement, some employees may be forced into telework at home in family settings that are disruptive of work, or surveillance of telework employees may infringe upon individual privacy. A Ukrainian study [97] argues that there is a need to develop and adopt a more comprehensive set of labour laws and codes around the area of remote work to preserve the labour rights of employees, and which also meet modern requirements of international and European labour law. This echoes arguments put forward by Hynes [100] in 2014, who argued that without such types of protections, the practice will be disorganised, and may not be as successful as it otherwise could be.

Nediari and colleagues [101] instead focus on the impact of telework or remote work on office space design, and how reduced office space density can be leveraged to improve worker health and environmental outcomes, while at the same time allowing the company access to the global talent pool.

Kapkaev and Rudenko [102] explored how training and learning on the job, especially working with digital platforms, is a key part of a company's transition to increased rates of telework, which will be critical for ensuring its competitiveness and worker health. This sentiment was echoed by Medina-Rodriguez et al. [103], who discussed the need for organisational strategy in ensuring an orderly transition to telework practices.

On the negative side, telework may be associated with overwork [70], and the type of mandated telework associated with COVID-19 lockdowns may also have increased workfamily conflict [64]. This is particularly problematic given it is often linked to $24 / 7$ access of employees by employers and customers. In response, Petryshyn and Hyliaka [98] note that, in 2016, France enacted a law enabling employees to turn off all digital communication during non-traditional working hours. More generally, many employees benefit from policies allowing segmentation of work and family time for teleworkers [64]. It is not obvious that strict standardisation would make sense in all countries, but the notion of restricting the reach of work into time spent on other aspects of life could help to make telework more sustainable in the long run.

An alternative form of telework may provide many of the advantages mentioned above without the physical isolation of work-from-home: co-working places [99]. As Kojo and Nenonen [99] note, co-working spaces have existed since the 1960s and can provide a workplace that is close to employee homes, flexible hours of operation, and length of the 
lease. Relative to traditional work-from-home telework, co-working places can enhance social supports among relevant employees, ensure access to relevant resources, such as high-speed internet, reduce interruptions, and provide face-to-face work opportunities for teams while minimising commuting time.

3.3.5. SDG 9: Build Resilient Infrastructure, Promote Inclusive and Sustainable Industrialisation and Foster Innovation

The aim of SDG 9 is to build resilient infrastructure and to promote inclusive and sustainable industrialisation and foster innovation. This was found to be a popular theme in the academic literature, as part of the broader conversation discussing the relationship between innovative new technologies and sustainability [118,119,121,122,125]. SDG 9 targets relevant in association with telework are shown in Box 5.

Box 5. SDG 9 targets relevant to telework.

9.1. Develop quality, reliable, sustainable and resilient infrastructure, including regional and transborder infrastructure, to support economic development and human well-being, with a focus on affordable and equitable access for all.

9.4. By 2030, upgrade infrastructure and retrofit industries to make them sustainable, with increased resource-use efficiency and greater adoption of clean and environmentally sound technologies and industrial processes, with all countries taking action in accordance with their respective capabilities.

Develop quality, reliable, sustainable and resilient infrastructure (9.1): Baker et al. [122] found that technology, and technology-related organisational support, played a crucial role in the growth of telework, and underlined the importance of providing telework training for non-telecommuting workers and managers to encourage further participation. During the large-scale disruption caused by COVID-19, adoption of telework has improved resilience of communities against such disruptions, and is also seen as a significant opportunity for fundamental change towards a more sustainable economy by Bezemer [123], who discussed why the pandemic has accelerated six changes that can influence policymaking, including the accelerated adoption of IT. Middleton [119] explored the argument that broadband Internet can be used as a tool to substitute physical activities with digital alternatives, such as work travel and meetings with telework and videoconferencing. However, it was found that the use of broadband to support telework, in addition to other functions such as online education and telemedicine, was still in its infancy at the time of the research.

Upgrade infrastructure and retrofit industries to make them sustainable (9.4): Chitrao [86] believes Generation Y's increased focus on work-life balance will have a significant impact on the future of work, resulting in more flexibility around times that work is conducted, and suggests technologies such as videoconferencing will reduce the overall requirement for work-related travel. They also predicted that human resource departments will need to offer employees a "compelling mix of rewards tailored to suit the individual employee's unique needs and preferences", and support initiatives that enable flexible work hours, cater for a variety of different work-life choices, and enable employees to fully develop their potential [86]. As part of a study investigating task antecedents of work engagement, and how task characteristics affect work engagement, Lee, Shin and Baek [118] examined whether it is necessary to have a decentralised and flexible work model to secure organisational sustainability in a rapidly changing environment. They concluded that technologies can significantly assist workers in working together because of the reduced time and space constraints they offer, and give workers more flexibility for maintaining personal relationships around their work commitments. Conversely, Fuchs [116] questioned the widespread belief that telework reduces overall travel, suggesting it generates new social relationships, which then lead to more travelling. However, the research was conducted at a time when teleworkers only comprised a small proportion of the total workforce, and work-related travel was believed to contribute only a small amount of $\mathrm{CO}_{2}$ emissions, so this may be worth revisiting from a post-COVID context. 
Kapkaev and Rudenko [102] argued that when switching to remote work, many employees faced problems, especially in implementing work at home. Many employees had an uncertain work situation related to the timing of remote work and the very essence of work activities. It was necessary to master new work programs, to interact with employees and clients online, in the shortest possible time. Many have faced difficulties in their work due to misunderstandings and ignorance of their remote work. Therefore, many managers solved these problems with their employees' training and professional development [102]. They argue that training and professional development is a key part of the digital transformation associated with telework, which can make significant contributions to productivity growth and environmental sustainability.

\subsubsection{SDG 10: Reduce Inequality within and among Countries}

The relevant target for SDG5 which aims to reduce inequality [4] is shown in Text Box 6. Generally, academic literature linking telework with SDG 10, which aims to reduce inequality within and among countries, is lacking in our sample.

Policies to increase greater equality (10.4): Nwokocha and Theriohanma [132] believe that globalisation has increased the mobility of today's labour market and that Nigeria can better compete on a global stage if they adopt several sustainability practices, one of which is flexible working to improve employees' work-life balance. The study hints that higher acceptance of remote work would allow greater regionalisation of workers, in addition to an increased employment opportunity for those working remotely and even in different countries to participate in labour markets, and this could work to reduce inequality. Similarly, Kapkaev and Rudenko [102] believe that remote work provides people with "the opportunity to earn money anywhere in the world, regardless of social status, health, education."

Box 6. SDG 10 target relevant to telework.

10.4. Adopt policies, especially fiscal, wage and social protection policies, and progressively achieve greater equality.

\subsubsection{SDG 11: Sustainable Cities and Communities}

Teleworking has important implications for cities and communities to become more safe, resilient, and sustainable. Relevant targets for SDG11 [4] are shown in Text Box 7.

Box 7. SDG 11 targets relevant to telework.

11.1. By 2030, ensure access for all to adequate, safe and affordable housing and basic services and upgrade slums.

11.2. By 2030, provide access to safe, affordable, accessible and sustainable transport systems for all, improving road safety, notably by expanding public transport, with special attention to the needs of those in vulnerable situations, women, children, persons with disabilities and older persons.

11.B. By 2020, substantially increase the number of cities and human settlements adopting and implementing integrated policies and plans towards inclusion, resource efficiency, mitigation and adaptation to climate change, resilience to disasters, and develop and implement, in line with the Sendai Framework for Disaster Risk Reduction 2015-2030, holistic disaster risk management at all levels

Urban form and housing (11.1): Kawai [66] explores, in the context of a Californian town, the potential benefits for vitalising a city by integrating teleworking policies in a holistic manner that incorporates appropriate urban design, housing stock, economic development, and ICT infrastructure. Generally, people living in more affluent areas and those with less public transport access are more likely to work from home [142]. Moos and Skaburskis [133] note the risk of urban sprawl arising from teleworking because 
those working from home tend to live in larger single-family homes, indicating the need to consider the mix of housing to support telework practices. Urban sprawl and lowdensity urban form are widely considered to be problematic in terms of sustainability outcomes [147-151], although a higher urban density does not necessarily lead to the desired outcomes [153].

Traffic congestion (11.2): The link between telework and traffic congestion has long been studied [141]. This is not surprising because traffic congestion causes major social and economic costs for cities and societies [152], and it is widely argued that as telecommuting reduces car travel in cities, this also reduces traffic congestion $[137,139,141]$. However, the size of the effect is unsurprisingly a function of how often individuals tend to work from home and their usual mode of transport [135]. As an illustrative example that indicates the size of potential benefits, Hensher et al. [134] quantified the annualised time and monetary cost savings for Sydney in 2020, which resulted from an extreme teleworking scenario during the lockdowns, at AUD 3.6 billion. In a post-COVID-19 world where teleworking has become a more widespread practice, there are opportunities for measuring and quantifying these effects in more detail.

Community resilience (11.B): It has been noted that teleworking can support community resilience to a range of shocks; for example, Campisi and Basbas note that teleworking is a mode of transport that allows work to continue despite fuel shocks, pandemics, or even natural or man-made disasters [137]. Hakovirta and Denuwara [139] note inequalities and associated vulnerability because this transport mode is primarily only available to those with Internet-ready homes that are set up for teleworking, indicating an issue of possible inequity. This also shows the important role of abundant Internet-ready homes in a resilient modern society. Bohman and colleagues [140] also noted that telework may exacerbate known differences in mobility-related gender and geography, and noted that this needs to be considered in transport policy.

\subsubsection{SDG 12: Ensure Sustainable Consumption and Production Patterns}

Telework changes the way that households consume natural resources and how they travel, and has the potential to shift communities towards a more digitally enabled future. The relevant targets for SDG12 [4] are shown in Text Box 8.

Box 8. SDG 12 targets relevant to telework.

12.2. By 2030, achieve the sustainable management and efficient use of natural resources.

12.A. Support developing countries to strengthen their scientific and technological capacity to move towards more sustainable patterns of consumption and production.

Reduce natural resource use (12.2): Telework is widely assumed to reduce the environmental impact and resource use of our societies [50,147,167], but Heinonen and Kuosa argued that this benefit is not automatic and, rather, telework needs to be designed to provide environmental benefits [143]. The link between telework and environmental sustainability is non-linear and dependent on context [145]; for example, in some circumstances, car dependence can be maintained in teleworking households [146]. Moreover, during lockdowns in response to COVID-19, which are considered to be an extreme case of teleworking practices, residential water demand increased by $14 \%$ in Germany [165] and by $20 \%$ in the UK [166]. This increase in residential water demand was likely matched by decreases in commercial water demand; nonetheless, shifting of demand patterns raises the issue of understanding how, in a scenario of high rates of teleworking, water infrastructure needs to be adapted to meet a new situation. There will be implications for pressure management, wastewater flows and treatment, and long-term infrastructure investments. Furthermore, during the recent lockdowns around the world, there have been reports of large increases in cycling and walking $[123,137]$. To put this into context, the OECD also reports the potential for significant improvements to productivity arising from the widespread adoption of telework [14]. It is 
also yet to be established whether teleworking practices that improve work-life balance will lead to more sustainable consumption patterns.

Scientific and technological capacity to move to sustainability (12.A): Teleworking has a broad impact on consumption more generally. For example, perhaps currently conflated by impacts of the current COVID-19 pandemic, telework tends to lead to accelerated adoption of IT systems and reduced demand for aviation [123]. In turn, the adoption of IT systems has been identified as an opportunity for implementing "smart cities" and an acceleration of advanced IT system adoption, such as cloud computing [163,165,166], which can enable more efficient traffic, waste management, energy management, etc.

\subsubsection{SDG 13: Take Urgent Action to Combat Climate Change and Its Impacts}

Several studies have contended that telework has an important role to play in climate action in jurisdictions such as the EU [172] and India [173], and that telecommuting should be embedded as an integral part of climate policies. The relevant target for SDG13 [4] is shown in Text Box 9.

Box 9. SDG 13 target relevant to telework.

13.2. Integrate climate change measures into national policies, strategies and planning.

Integrate climate change measures into national policies, strategies and planning (13.2): Telework has significant potential to reduce greenhouse gas emissions while also meeting social and economic goals [42]. It is estimated that telework generally reduces greenhouse gas emissions because less car-based mobility is required for commuting $[45,46,135,137,162,167-169]$. However, it has been noted that telecommuters sometimes have to make additional trips for activities that were normally carried out while commuting, generally leading to an increase in non-commuting travel $[46,136,138,173]$, although evidence suggests that the increase in non-commuting travel is likely less than the expected reduction in car-based commuting travel [168]. It has also been widely noted that the overall reduction of greenhouse gas emissions is a function of the travel mode of commuters and the number of days worked from home $[171,173,174]$. Furthermore, based on a US study, negating some of the benefits of telework, Zhu and Mason [169] found that workers who telecommute tend to be more car dependent and, on average, travel more than their office-based counterparts, and that this effect increases the longer they have worked from home. However, there is a very large variability in estimates of changes in travel-based greenhouse gas emissions in different studies [170], with many studies, such as that of Alonso et al. [171] undertaken in Spain, reporting a large reduction in emissions. The study of Moos and Skaburskis [133] may provide an explanation for the findings of Zhu and Mason [169], namely, that people who work from home are more likely to live in larger single-family dwellings that are associated with urban sprawl and higher car dependence. Indications are that the net positive effect of telework is greater in cities with less sprawl and car dependence. This indicates an important nexus between the availability of appropriate housing, urban mobility, and telework, with critical implications for greenhouse gas emissions $[171,173,174]$.

Energy use: The other hypothesised change in greenhouse gas emissions arises because the reduction in energy use in the office is greater than the increased energy use at home [170]. Unsurprisingly, the pattern of energy use in the home changes significantly for those who telework, and this can be managed and measured using smart sensors [176]. During the COVID-19 lockdowns, the net electricity demand decreased in several locations $[162,174]$, with an increase in residential electricity use more than offset by larger reductions in commercial electricity use. The increase in residential energy use can furthermore be mitigated using relatively simple energy efficiency measures, and the adoption of solar PV systems and batteries [174]. Research also indicates that unless there is widespread adoption of telecommuting — beyond "just a day or two a week" — the reduction in office 
energy use may be only marginal $[170,177]$. This is in part because even unoccupied office buildings tend to use nearly half of the energy of fully occupied buildings [175]. This research shows that when telecommuting is embedded into climate policies, it is important to acknowledge the risk of further urban sprawl and the increased car dependence that this may trigger, and that policies to promote telecommuting should be combined with policies that promote (1) a shift away from car dependence to low-carbon transport modes, such as active or public transport; and (2) increased adoption of residential energy efficiency and solar PVs or batteries when appropriate.

\section{Strengths, Weaknesses, Opportunities and Threats}

The SWOT analysis technique was adopted to visualise the key strengths, weaknesses, opportunities, and threats to sustainability, likely arising from an increase in the adoption of telework, as explored in the previous academic literature (see Figure 5).

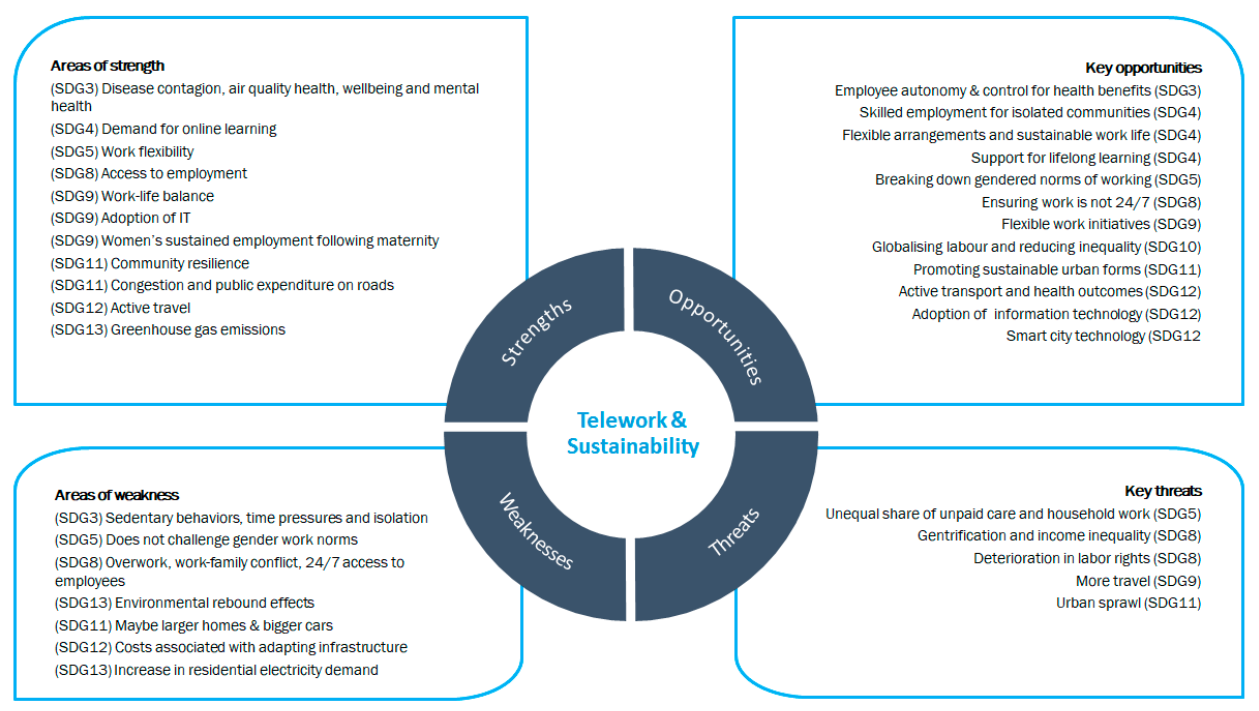

Figure 5. SWOT analysis.

Examples of some of the key strengths that were identified include the overarching fact that telework supports flexible work arrangements, promotes work-life balance, helps new parents sustain employment, reduces congestion, and improves air quality and traffic safety. However, weaknesses were also identified, including the potential for homes and cars to increase in size due to telework, the possibility of net increases in electricity demand/usage, and rebound effects limiting the long-term potential of any environmental benefits gained from increased telework. Furthermore, when considering the threats posed by an expansion of telework, it has been suggested that, in some circumstances, there is a rebound effect that may result in more travel, contribute to an increase in urban sprawl, require expensive changes to current infrastructure, and create an unequal gender distribution for unpaid care and household work.

Most importantly, this technique has enabled the researchers to identify and illustrate several key opportunities for generating benefits and mitigating risks:

- One area that warrants further investigation is telework's capacity for offering skilled employment to people living in isolated communities who may have previously been excluded from numerous opportunities due to geographical distance. Advances in this area could contribute to a greater globalisation of labour and address the inequalities that currently exist within and between countries.

- Similarly, further research is needed into the role of flexible work initiatives, and how these can be designed to support different work-life choices and circumstances. This line of investigation could examine the role of telework in supporting lifelong 
learning, and in offering more employment opportunities to people with disabilities, new parents, carers, or anyone excluded from current employment opportunities due to the requirement of being physically present during work hours.

- Future research could also investigate telework's potential to comprehensively promote sustainable urban forms and regionalisation, encourage improved human health and environmental sustainability, achieve productivity and innovation increases, and act as the focal point for smart city technology and transport solutions.

- The potential impact of telework on water and energy use, in terms of diurnal and spatial patterns of use, and the net impact on the requirements for water and energy infrastructure, are still somewhat unclear. Strategic investment in infrastructure is likely to be required to support and promote resource efficiency and the effective delivery of urban services, in future scenarios in which telework is more common.

\section{Knowledge Gaps}

Our research identified several knowledge gaps that need to be explored further if telework is to be integrated into comprehensive plans to achieve SDGs. These are further explored below.

Telework and policy integration/coherence: We found a large number of academic articles exploring how different dimensions of telework may impact a series of SDGs, indicating that any policy on telework that aims to promote SDGs needs to carefully consider trade-offs, the potential to mitigate any negative consequences, and any strategy to maximise benefits. There is also a need to further research any missing links between telework and a selection of SDGs (see list in Introduction, i.e., SDGs 1, 2, 6, 7, 14, 15, 16, and 17) for which we have not yet discovered any previous research. From a policy perspective, the complex impacts of telework on a range of sustainability outcomes indicates (1) the need for academic articles that explore telework in a more holistic sense across multiple SDGs; and (2) an urgent need for academic research leading to a comprehensive policy framework that ensures that efforts to achieve one SDG do not undermine efforts to achieve another-that is, policy coherence. In essence, there is a strong need for policy integration and holistic decision making around telework, in alignment with discussions by Bornemann and Weiland [190], as being necessary to achieve the UN 2030 agenda and associated SDGs. It is recommended that further research is undertaken to explore how policy coherence for telework can be ensured.

Developing countries: The vast majority of academic articles $(84 \%)$ in our review come from developed nations, while the UN SDGs to a large extent refer to issues in developing nations; thus, it is reasonable to question whether benefits and risks arising from telework are the same in all contexts and whether results are applicable in areas where the SDGs primarily apply. There is a need to further explore the impacts of telework in regions not currently well-covered by academic literature (see Table 2 and Figure 2).

Substance abuse: No articles explore the link between telework and substance abuse. However, a desktop scan of articles found using a Google Scholar search shows this is a topic that perhaps should be explored further. For example, one online article [191], describes psychologists who report on their clients struggling with increased alcohol abuse as an indirect result of lockdown and working from home. In addition, the activist organisation American Addiction Centers found through a survey that about one-third of those working from home were likely to be drinking more alcohol [192].

Equality implications: Several articles noted the improved access to employment that could arise from greater adoption of telework, but only one article explored the impact of telework on equality in more detail. Given the existing inequality in access to telework and the appropriate housing that needs to support home-based work, this is an under-explored research topic.

Gender equality and domestic abuse: A topic commonly encountered in the public discourse associated with COVID-19 lockdowns concerns the increase in domestic abuse that has occurred during lockdowns, and this issue is to some extent explored in the 
academic literature [193-197]. However, we did not encounter any research in our sample that linked this effect with telework, and further research appears to be necessary to explore this link.

Environmental impacts and urban form: Although the weight of evidence strongly points in the direction that there are some significant environmental benefits associated with telework, this to some extent hinges on how the city supports the shift in population behaviour. Further research is required to explore, in a co-design manner as per Webb et al. [198], the type of urban form, urban planning, and infrastructure that will simultaneously support environmental sustainability, economic productivity, and employee flexibility.

\section{Conclusions}

This research explored, through a scoping review, how the increased adoption of telework in its various forms may impact sustainability outcomes, specifically those related to SDG achievement. We believe that this is very timely, due to the emergence of the hybrid work model as a popular work arrangement for many organisations in the post-COVID-19 era, which will mean many workers continue to practice telework in the future, at least part of the time.

Based on the review, several strengths, weaknesses, opportunities, and threats were identified, across nine separate SDG areas. Telework as a practice has diverse impacts, indicating that there is a need for careful consideration of both the value that can be accrued and how such value can be amplified, in addition to the associated risks, many of which can be mitigated and managed. This shows the need to develop an integrated and holistic telework policy framework, in a manner that can promote policy coherence.

Specifically, the advantages of telework are that it may support action to combat climate change; may help improve air quality and reduce associated ill health and death; can promote active travel and associated health benefits; can improve work-life balance and work flexibility; supports community resilience at a time of crisis; reduces congestion on roads; may reduce public expenditure on roads; can support the more active participation of women and marginalised groups in the workforce; and provides greater access to employment in regions.

Telework's disadvantages are that it may increase sedentary behaviours, stress and social isolation; can increase rates of overwork and domestic conflict; may increase residential energy demand; may lead to deterioration in labour rights; and, depending on circumstances, can cause rebound effects that may lead to increased urban sprawl and gentrification that would undermine environmental benefits.

It should be noted that many of the risks can be managed, and that the benefits and weaknesses depend strongly on context. For example, the size of the environmental rebound effect depends on the urban form, including walkability and access to local services. Similarly, the potential deterioration in labour rights may be mitigated by the adoption of appropriate policy and legal frameworks.

In undertaking the review, we also identified that research into links between telework and sustainability have increased significantly in recent years; nonetheless, the final sample of relevant literature was still relatively small. The presence of a geographic knowledge gap was detected, with the vast majority of research having been conducted in the "Europe and North America" region, underlining the need for more research in countries classified as having a low or medium human development index, particularly Oceania, Northern Africa, and Western Asia, where no previous academic studies were detected.

The authors believe this work makes a significant contribution to the academic body of knowledge in an area that intersects a wide range of economic, societal, and environmental interests. It is also intended to act as a guide to inform practitioners and policy makers seeking to better understand the wider implications for long-term telework, and assist them to mitigate any negative consequences and promote the positive aspects of telework. 
Finally, links between telework and eight other SDG areas did not emerge from our search of the literature. Thus, there may be opportunities for future research that investigates possible relationships between telework and SDG areas such as no poverty, zero hunger, and affordable clean energy.

Author Contributions: Conceptualization, M.M., J.H., A.B.; methodology, M.M., J.H., A.B.; investigation, M.M., J.H., A.B.; writing, M.M., J.H., A.B. All authors have read and agreed to the published version of the manuscript.

Funding: This research received no external funding.

Institutional Review Board Statement: Not applicable.

Informed Consent Statement: Not applicable.

Data Availability Statement: Not applicable.

Conflicts of Interest: The authors declare no conflict of interest.

\section{References}

1. Steffen, W.; Richardson, K.; Rockström, J.; Cornell, S.E.; Fetzer, I.; Bennett, E.M.; Biggs, R.; Carpenter, S.R.; De Vries, W.; De Wit, C.A.; et al. Planetary boundaries: Guiding human development on a changing planet. Science 2015, 347, 1217. [CrossRef]

2. IPCC. Climate Change 2021: The Physical Science Basis. Contribution of Working Group I to the Sixth Assessment Report of the Intergovernmental Panel on Climate Change; IPCC: Geneva, Switzerland, 2021.

3. Raworth, K. Doughnut Economics: Seven Ways to Think Like a 21st Century Economist; Penguin: London, UK, 2017.

4. United Nations. The 17 Goals. Available online: https://sdgs.un.org/goals (accessed on 16 June 2021).

5. Liu, Z.; Ciais, P.; Deng, Z.; Lei, R.; Davis, S.J.; Feng, S.; Zheng, B.; Cui, D.; Dou, X.; Zhu, B.; et al. Near-real-time monitoring of global $\mathrm{CO}_{2}$ emissions reveals the effects of the COVID-19 pandemic. Nat. Commun. 2020, 11, 5172. [CrossRef]

6. Brown, L.; Barnes, J.; Hayes, E. Traffic-related air pollution reduction at UK schools during the Covid-19 lockdown. Sci. Total. Environ. 2021, 780, 146651. [CrossRef]

7. Giovanis, E. The relationship between teleworking, traffic and air pollution. Atmos. Pollut. Res. 2018, 9, 1-14. [CrossRef]

8. Moglia, M.; Frantzeskaki, N.; Newton, P.; Pineda Pinto, M.; Witheridge, J.; Cook, S.; Glackin, S. Accelerating a green recovery of cities: Lessons from a scoping review and a proposal for mission-oriented recovery towards post-pandemic urban resilience. Dev. Built Environ. 2021, 7, 100052. [CrossRef]

9. Beck, M.J.; Hensher, D.A.; Wei, E. Slowly coming out of COVID-19 restrictions in Australia: Implications for working from home and commuting trips by car and public transport. J. Transp. Geogr. 2020, 88, 102846. [CrossRef]

10. Raišienè, A.G.; Rapuano, V.; Varkulevičiūtè, K.; Stachová, K. Working from Home-Who Is Happy? A Survey of Lithuania's Employees during the COVID-19 Quarantine Period. Sustainability 2020, 12, 5332. [CrossRef]

11. López-Igual, P.; Rodríguez-Modroño, P. Who is teleworking and where from? Exploring the main determinants of telework in Europe. Sustainability 2020, 12, 8797. [CrossRef]

12. Nguyen, M.H.; Armoogum, J. Perception and preference for home-based telework in the covid-19 era: A gender-based analysis in Hanoi, Vietnam. Sustainability 2021, 13, 3179. [CrossRef]

13. Belzunegui-Eraso, A.; Erro-Garcés, A. Teleworking in the context of the Covid-19 crisis. Sustainability 2020, 12, 3662. [CrossRef]

14. OECD. Productivity Gains from Teleworking in the Post COVID-19 Era: How Can Public Policies Make it Happen; OECD: Paris, France, 2020.

15. Bloom, N. Hybrid is the Future of Work; Stanford Institute for Economic Policy Research (SIEPR): Stanford, CA, USA, 2021.

16. Tàbara, J.D.; Frantzeskaki, N.; Hölscher, K.; Pedde, S.; Kok, K.; Lamperti, F.; Christensen, J.H.; Jäger, J.; Berry, P. Positive tipping points in a rapidly warming world. Curr. Opin. Environ. Sustain. 2018, 31, 120-129. [CrossRef]

17. Banjo, S.; Yap, L.; Murphy, C.; Chan, V. The World's Biggest Work-From-Home Experiment. Available online: https://www. bloomberg.com/news/articles/2020-02-02/coronavirus-forces-world-s-largest-work-from-home-experiment (accessed on 13 August 2021).

18. Goffman, E. In the wake of COVID-19, is glocalization our sustainability future? Sustain. Sci. Pract. Policy 2020, 16, 48-52. [CrossRef]

19. Moglia, M.; Cork, S.; Cook, S.; Muster, T.; Bohensky, E. The Future of Sydney: Scenarios to Guide Collaboration by the Sydney Common Planning Assumptions Group; CSIRO: Sydney, NSW, Australia, 2019.

20. Moglia, M.; Cork, S.J.; Boschetti, F.; Cook, S.; Bohensky, E.; Muster, T.; Page, D. Urban transformation stories for the 21st century: Insights from strategic conversations. Glob. Environ. Chang. 2018, 50, 222-237. [CrossRef]

21. Elldér, E. Telework and daily travel: New evidence from Sweden. J. Transp. Geogr. 2020, 86, 102777. [CrossRef]

22. Queiroz, M.M.; Ivanov, D.; Dolgui, A.; Wamba, S.F. Impacts of epidemic outbreaks on supply chains: Mapping a research agenda amid the COVID-19 pandemic through a structured literature review. Ann. Oper. Res. 2020, 1-38. [CrossRef] 
23. Hopkins, J. An investigation into emerging industry 4.0 technologies as drivers of supply chain innovation in Australia. Comput. Ind. 2021, 125, 103323. [CrossRef]

24. Inoue, H.; Todo, Y. The propagation of economic impacts through supply chains: The case of a mega-city lockdown to prevent the spread of COVID-19. PLoS ONE 2020, 15, e0239251. [CrossRef]

25. Paul, S.K.; Chowdhury, P. A production recovery plan in manufacturing supply chains for a high-demand item during COVID-19. Int. J. Phys. Distrib. Logist. Manag. 2020, 515, 104-125. [CrossRef]

26. Kramer, A.; Kramer, K.Z. The potential impact of the Covid-19 pandemic on occupational status, work from home, and occupational mobility. 2020, 119, 103442. J. Vocat. Behav. 2020, 119, 103442. [CrossRef]

27. Falchetta, G.; Noussan, M. The Impact of COVID-19 on Transport Demand, Modal Choices, and Sectoral Energy Consumption in Europe. In Proceedings of the IAEE Energy Forum, Special Issue 2020, Online, 4-7 July 2021; pp. 48-50.

28. Bourzac, K. COVID-19 Lockdowns Had Strange Effects on Air Pollution across the Globe. Available online: https://cen.acs.org/ environment/atmospheric-chemistry/COVID-19-lockdowns-had-strange-effects-on-air-pollution-across-the-globe/98/i37 (accessed on 26 March 2021).

29. Chen, C.; Chen, B.; Wang, B.; Huang, C.; Zhao, J.; Dai, Y.; Kan, H. Low-carbon energy policy and ambient air pollution in Shanghai, China: A health-based economic assessment. Sci. Total Environ. 2007, 373, 13-21. [CrossRef]

30. NASA. NASA Model Reveals How Much COVID-related Pollution Levels Deviated from the Norm. Available online: https: / / www.nasa.gov / feature/goddard/2020/nasa-model-reveals-how-much-covid-related-pollution-levels-deviatedfrom-the-norm (accessed on 24 March 2021).

31. Venter, Z.S.; Aunan, K.; Chowdhury, S.; Lelieveld, J. COVID-19 lockdowns cause global air pollution declines. Proc. Natl. Acad. Sci. USA 2020, 117, 18984-18990. [CrossRef]

32. Sander, L. Coronavirus could spark a revolution in working from home. Are we ready. Conversation 2020, 11. Available online: https:/ / theconversation.com/coronavirus-could-spark-a-revolution-in-working-from-home-are-we-ready-133070 (accessed on 26 June 2021).

33. YLE. Covid-Era Telecommuting behind 30\% Drop in Heart Attacks, Chief Doc Says. Available online: https://yle.fi/uutiset/ osasto/news/covid-era_telecommuting_behind_30_drop_in_heart_attacks_chief_doc_says/11949701 (accessed on 13 August 2021).

34. Liu, S.; Su, Y. The impact of the Covid-19 pandemic on the demand for density: Evidence from the US housing market. Econ. Lett. 2020, 2024, 110010 .

35. Lenaghan, N. Tower values to tumble as rents crumble. Aust. Financ. Rev. 2020, 2020. Available online: https://www.afr.com/ property/commercial/tower-values-to-tumble-as-rents-crumble-20200724-p55f99 (accessed on 26 June 2021).

36. Danckert, S. NAB to 'mothball' Docklands headquarters as Victoria locks down. Syd. Morning Her. 2020, 2020. Available online: https:/ / www.smh.com.au/business/companies/nab-to-mothball-docklands-headquarters-as-victoria-locks-down-20 200701-p557zi.html (accessed on 26 June 2021).

37. Accenture. The Future of Work: Productive Anywhere; Accenture: New York, NY, USA, 2021.

38. Moglia, M.; Cook, S.; McGregor, J. A review of Agent-Based Modelling of technology diffusion with special reference to residential energy efficiency. Sustain. Cities Soc. 2017, 31, 173-182. [CrossRef]

39. Moglia, M.; Podkalicka, A.; McGregor, J. An Agent-Based Model of Residential Energy Efficiency Adoption. J. Artif. Soc. Soc. Simul. 2018, 21, 3. [CrossRef]

40. Ajzen, A.I. Attitudes, Behaviour, Personality; Dorsey: Chicago, IL, USA, 1988.

41. Akbari, M.; Hopkins, J.L. An investigation into anywhere working as a system for accelerating the transition of Ho Chi Minh city into a more livable city. J. Clean. Prod. 2019, 209, 665-679. [CrossRef]

42. Basso, R.B.F.; Battistelle, R.A.G.; Cavenaghi, V. Telework and management: Technology for a more sustainable environment. In Proceedings of the 22nd International Conference on Production Research, ICPR 2013, Iguassu Falls, Brazil, 28 July-1 August 2013.

43. Graizbord, B. Teleworking as a Mobility Strategy for Mexico City. Int. Plan. Stud. 2015, 20, 112-130. [CrossRef]

44. Johnson, L.C. Bringing work home: Developing a model residentially-based telework facility. Can. J. Urban Res. 1999, 8, 119-142.

45. Kim, S.N. Is telecommuting sustainable? An alternative approach to estimating the impact of home-based telecommuting on household travel. Int. J. Sustain. Transp. 2017, 11, 72-85. [CrossRef]

46. Muto, D.; Yokoo, N.; Fujiwara, K. Reduction of Environmental Load by Telecommuting in Oku-Nikko. In Proceedings of the IOP Conference Series: Earth and Environmental Science, Tokyo, Japan, 6-7 August 2019; Volume 294.

47. Tintin, R.A.; Vela, M.; Bravo, X.; Anzules, V. Teleworking: An alternative to improve mobility in Ecuador. In Proceedings of the 2014 1st International Conference on eDemocracy and eGovernment, ICEDEG 2014, Quito, Ecuador, 24-25 April 2014 ; pp. 85-89.

48. Wang, Q.; Hu, H. Rise of interjurisdictional commuters and their mode choice: Evidence from the chicago metropolitan area. $J$. Urban Plan. Dev. 2017, 143, 05017004. [CrossRef]

49. Beck, M.J.; Hensher, D.A. Insights into the impact of COVID-19 on household travel and activities in Australia-The early days of easing restrictions. Transport. Policy 2020, 99, 95-119. [CrossRef] [PubMed]

50. Atlassian. The 2021 State of Remote Work; Atlassian: Sydney, Australia, 2021.

51. Global Workplace Analytics. Work From Home Experience Survey Results. Available online: https://globalworkplaceanalytics. com/global-work-from-home-experience-survey (accessed on 19 March 2021). 
52. Koehn, E.; Irvine, J. The Five-Day Office Week is Dead, Long Live the Hybrid Model, Says Productivity Boss. Available online: https:/ / www.smh.com.au/business/companies/the-five-day-office-week-is-dead-long-live-the-hybrid-model-saysproductivity-boss-20210706-p587d4.html (accessed on 9 August 2021).

53. Pham, M.T.; Rajić, A.; Greig, J.D.; Sargeant, J.M.; Papadopoulos, A.; McEwen, S.A. A scoping review of scoping reviews: Advancing the approach and enhancing the consistency. Res. Synth. Methods 2014, 5, 371-385. [CrossRef] [PubMed]

54. Arksey, H.; O'Malley, L. Scoping studies: Towards a methodological framework. Int. J. Soc. Res. Methodol. 2005, 8, 19-32. [CrossRef]

55. Mays, N.; Roberts, E.; Popay, J. Synthesising Research Evidence. In Studying the Organisation and Delivery of Health Services: Research Methods; Fulop, N., Allen, P., Clarke, A., Black, N., Eds.; Routledge: London, UK, 2001.

56. Fulop, N. Studying the Organisation and Delivery of Health Services: Research Methods; Psychology Press: East Sussex, UK, 2001.

57. Higgins, J.P.; Thomas, J.; Chandler, J.; Cumpston, M.; Li, T.; Page, M.J.; Welch, V.A. Cochrane handbook for Systematic Reviews of Interventions; John Wiley \& Sons: Hoboken, NJ, USA, 2019.

58. Hoffman, K.E.; Garner, D.; Koong, A.C.; Woodward, W.A. Understanding the Intersection of Working from Home and Burnout to Optimize Post-COVID19 Work Arrangements in Radiation Oncology. Int. J. Radiat. Oncol. Biol. Phys. 2020, 108, 370-373. [CrossRef]

59. Chao, M.; Shih, C.T.; Hsu, S.F. Nurse occupational burnout and patient-rated quality of care: The boundary conditions of emotional intelligence and demographic profiles. Jpn. J. Nurs. Sci. 2016, 13, 156-165. [CrossRef]

60. Karanika-Murray, M.; Biron, C. The health-performance framework of presenteeism: Towards understanding an adaptive behaviour. Hum. Relat. 2020, 73, 242-261. [CrossRef]

61. Lindgren, I.; Brogårdh, C.; Pessah-Rasmussen, H.; Jonasson, S.B.; Gard, G. Work conditions, support, and changing personal priorities are perceived important for return to work and for stay at work after stroke-A qualitative study. Disabil. Rehabil. 2020, 1-7. [CrossRef]

62. Dima, A.M.; Tuclea, C.E.; Vrânceanu, D.M.; Tigu, G. Sustainable social and individual implications of telework: A new insight into the Romanian labor market. Sustainability 2019, 11, 3506. [CrossRef]

63. Galvez, A.; Tirado, F.; Mart-nez, M.J. Work-life balance, organizations and social sustainability: Analyzing female telework in Spain. Sustainability 2020, 12, 3567. [CrossRef]

64. Waples, E.P.; Brock Baskin, M.E. Not Your Parents' Organization? Human Resource Development Practices for Sustainable Flex Work Environments. Adv. Dev. Hum. Resour. 2021, 23, 153-170. [CrossRef]

65. Schellhammer, S.; Klein, S.; Ebner, E. Primary prevention for employees in the Information Age Organization. Health Policy Technol. 2017, 6, 72-82. [CrossRef]

66. Kawai, Y. Work/life community by telework-possibilities and issues in the case of loma linda. J. Green Build. 2008, 3, 128-139. [CrossRef]

67. Rubin, O. Contact between parents and adult children: The role of time constraints, commuting and automobility. J. Transp. Geogr. 2015, 49, 76-84. [CrossRef]

68. Vesala, H.; Tuomivaara, S. Slowing work down by teleworking periodically in rural settings? Pers. Rev. 2015, 44, 511-528. [CrossRef]

69. Olsen, H.M.; Brown, W.J.; Kolbe-Alexander, T.; Burton, N.W. Physical activity and sedentary behaviour in a flexible office-based workplace: Employee perceptions and priorities for change. Health Promot. J. Aust. 2018, 29, 344-352. [CrossRef] [PubMed]

70. Reed, A.; Hunton, J.E.; Norman, C.S. A Postmodern Stakeholder Analysis of Telework. Adv. Account. Behav. Res. 2006, 9, 209-235. [CrossRef]

71. Thulin, E.; Vilhelmson, B.; Johansson, M. New telework, time pressure, and time use control in everyday life. Sustainability 2019, 11, 3067. [CrossRef]

72. Nijland, L.; Dijst, M. Commuting-related fringe benefits in the Netherlands: Interrelationships and company, employee and location characteristics. Transp. Res. Part A Policy Pract. 2015, 77, 358-371. [CrossRef]

73. Drywień, M.E.; Hamulka, J.; Zielinska-Pukos, M.A.; Jeruszka-Bielak, M.; Górnicka, M. The COVID-19 pandemic lockdowns and changes in body weight among Polish women. A cross-sectional online survey PLifeCOVID-19 Study. Sustainability 2020, 12, 7768. [CrossRef]

74. Zogal, V.; Domènech, A.; Emekli, G. Stay at (which) home: Second homes during and after the COVID-19 pandemic. J. Tour. Futures 2020, in press. [CrossRef]

75. El Zowalaty, M.E.; Young, S.G.; Järhult, J.D. Environmental impact of the COVID-19 pandemic-a lesson for the future. Infect. Ecol. Epidemiol. 2020, 10, 1768023. [CrossRef]

76. Kitou, E.; Horvath, A. External air pollution costs of telework. Int. J. Life Cycle Assess. 2008, 13, 155-165. [CrossRef]

77. Eregowda, T.; Chatterjee, P.; Pawar, D.S. Impact of lockdown associated with COVID19 on air quality and emissions from transportation sector: Case study in selected Indian metropolitan cities. Environ. Syst. Decis. 2021, 1-12. [CrossRef]

78. Leh, O.L.H.; Marzukhi, M.A.; Kwong, Q.J.; Mabahwi, N.A. Impact of urban land uses and activities on the ambient air quality in Klang Valley, Malaysia from 2014 to 2020. Plan. Malays. 2020, 18, 239-258. [CrossRef]

79. Angeloni, S.; Borgonovi, E. An ageing world and the challenges for a model of sustainable social change. J. Manag. Dev. 2016, 35, 464-485. [CrossRef] 
80. France, E.F.; Akselsen, S.; Jones, M.L.R.; Tracey, K. Telework and quality of life: Some social impacts and practical implications. J. Inst. Br. Telecommun. Eng. 2002, 3, 57-66.

81. Goswami, S.; Pandey, G.G. The impact of flexi timing as a strategic tool for employee retention: A study of millennial (Singapore). J. Adv. Res. Dyn. Control Syst. 2019, 11, 405-415. [CrossRef]

82. Bjursell, C.; Bergmo-Prvulovic, I.; Hedegaard, J. Telework and lifelong learning. Front. Sociol. 2021, 6, 642277. [CrossRef] [PubMed]

83. Denkenberger, D.; Way, J.; Pearce, J.M. Educational pathways to remote employment in isolated communities. J. Hum. Secur. 2015, 11, 34-44. [CrossRef]

84. Wang, Z.-Y.; Zhang, L.-J.; Liu, Y.-H.; Jiang, W.-X.; Tang, S.-L.; Liu, X.-Y. Process evaluation of E-learning in continuing medical education: Evidence from the China-Gates Foundation Tuberculosis Control Program. Infect. Dis. Poverty 2021, $10,1-11$. [CrossRef] [PubMed]

85. Kizilcec, R.F.; Makridis, C.A.; Sadowski, K.C. Pandemic response policies' democratizing effects on online learning. Proc. Natl. Acad. Sci. USA 2021, 118, e2026725118. [CrossRef] [PubMed]

86. Chitrao, P.V. Strategic HR for sustainable business in technology driven 21st C. Indian J. Sci. Technol. 2015, 8, 69-75. [CrossRef]

87. Blake-Beard, S.; O'Neill, R.; Ingols, C.; Shapiro, M. Social sustainability, flexible work arrangements, and diverse women. Gend. Manag. 2010, 25, 408-425. [CrossRef]

88. Tomlinson, J.; Baird, M.; Berg, P.; Cooper, R. Flexible careers across the life course: Advancing theory, research and practice. Hum. Relat. 2018, 71, 4-22. [CrossRef]

89. Fathima, F.N.; Awor, P.; Yen, Y.C.; Gnanaselvam, N.A.; Zakham, F. Challenges and coping strategies faced by female scientists-A multicentric cross sectional study. PLoS ONE 2020, 15, e0238635. [CrossRef]

90. Chung, H.; Van der Horst, M. Women's employment patterns after childbirth and the perceived access to and use of flexitime and teleworking. Hum. Relat. 2018, 71, 47-72. [CrossRef] [PubMed]

91. Fereday, J.; Oster, C. Managing a work-life balance: The experiences of midwives working in a group practice setting. Midwifery 2010, 26, 311-318. [CrossRef]

92. Ling, F.Y.Y.; Leow, L. Enabling knowledge flow: Retaining graduate women in the Singapore construction industry. J. Constr. Dev. Ctries. 2008, 13, 65-82.

93. Thang, L.L. Population aging, older workers and productivity issues: The case of Singapore. J. Comp. Soc. Welf. 2011, 27, 17-33. [CrossRef]

94. Shacklock, K.; Brunetto, Y. A model of older workers' intentions to continue working. Pers. Rev. 2011, 40, 252-274. [CrossRef]

95. van Gorp, D.A.M.; van der Klink, J.J.L.; Abma, F.I.; Jongen, P.J.; van Lieshout, I.; Arnoldus, E.P.J.; Beenakker, E.A.C.; Bos, H.M.; van Eijk, J.J.J.; Fermont, J.; et al. The capability set for work-correlates of sustainable employability in workers with multiple sclerosis. Health Qual. Life Outcomes 2018, 16, 113. [CrossRef]

96. Vecchio, N. Labour force participation of families coping with a disabling condition. Econ. Anal. Policy 2015, 45, 1-10. [CrossRef]

97. Gusarov, S.M.; Melnyk, K.Y. New approaches to legal regulation and organisation of labour in Ukraine. J. Natl. Acad. Leg. Sci. Ukr. 2021, 28, 169-178. [CrossRef]

98. Petryshyn, O.V.; Hyliaka, O.S. Human rights in the digital age: Challenges, threats and prospects. J. Natl. Acad. Leg. Sci. Ukr. 2021, 28, 16-23.

99. Kojo, I.; Nenonen, S. Evolution of co-working places: Drivers and possibilities. Intell. Build. Int. 2017, 9, 164-175. [CrossRef]

100. Hynes, M. Telework Isn't working: A policy review. Econ. Soc. Rev. 2014, 45, 579-602.

101. Nediari, A.; Roesli, C.; Simanjuntak, P.M. Preparing post Covid-19 pandemic office design as the new concept of sustainability design. In Proceedings of the IOP Conference Series: Earth and Environmental Science, Jakarta, Indonesia, 23-24 June 2020; Volume 729.

102. Kapkaev, I.; Rudenko, D. Resource-efficient human capital use in the context of technological changes and sustainable development. In Proceedings of the E3S Web of Conferences, Chelyabinsk, Russia, 17-19 February 2021.

103. Medina-Rodríguez, C.E.; Casas-Valadez, M.A.; Faz-Mendoza, A.; Castorena-Robles, A.; Gamboa-Rosales, N.K. Decision management in the telework context: Trends, challenges and implications. In Proceedings of the International Conference on e-Learning, ICEL, Cairo, Egypt, 14-15 December 2020; pp. 307-311.

104. Bauer, W.; Hämmerle, M.; Gerlach, S. Smart tool for flexible human resource management in manufacturing under volatile markets. In Proceedings of the 23rd International Conference for Production Research, ICPR 2015, Manila, Philippines, 2-6 August 2015.

105. Blount, Y. Telework: Not business as Usual. In Business Technologies in Contemporary Organizations: Adoption, Assimilation, and Institutionalization; IGI Global: Hershey, PA, USA, 2014; pp. 76-95.

106. Blount, Y. Management skills and capabilities in an era of technology disruption. In Remote Work and Collaboration: Breakthroughs in Research and Practice; IGI Global: Hershey, PA, USA, 2017; Volumes 1-2, pp. 176-191.

107. Dhanakumar, V.G. Self-efficacy of the board of directors (BODs) for the management of rubber producers' society (RPS) of India. J. Rural Dev. 2001, 20, 447-488.

108. George, M.S.; Pant, S.; Devasenapathy, N.; Ghosh-Jerath, S.; Zodpey, S.P. Motivating and demotivating factors for community health workers: A qualitative study in urban slums of Delhi, India. WHO South-East Asia J. Public Health 2017, 6, 82-89. [CrossRef] 
109. Kirby, E.; Broom, A.; Karikios, D.; Harrup, R.; Lwin, Z. Exploring the impact and experience of fractional work in medicine: A qualitative study of medical oncologists in Australia. BMJ Open 2019, 9, e032585. [CrossRef]

110. Kossek, E.E.; Ollier-Malaterre, A. Desperately seeking sustainable careers: Redesigning professional jobs for the collaborative crafting of reduced-load work. J. Vocat. Behav. 2020, 117, 103315. [CrossRef]

111. Smith, N.; McDonald, P. Facilitating sustainable professional part-time work: A question of design? J. Manag. Organ. 2016, 22, 205-223. [CrossRef]

112. Sutcliffe, J.E.; Dhakal, S.P. Youth unemployment amidst aged care workers shortages in Australia: Why care about the millennials? Equal. Divers. Incl. 2018, 37, 182-198. [CrossRef]

113. Moriset, B. Teleworking, telecommuting, nomadic work: Space, place and the emergence of new workplace and production flexibilities. CyberGeo 2004, 2004. [CrossRef]

114. Murthy, V.; Guthrie, J. Accounting for workplace flexibility: Internal communication in an Australian financial institution. Account. Res. J. 2013, 26, 109-129. [CrossRef]

115. Andrés, M.R.; Broncano, S.G.; Monsalve, J.N.M. Could innovative teams provide the necessary flexibility to compete in the current context? Cuad. Gestión 2015, 15, 145-163. [CrossRef]

116. Fuchs, C. The implications of new information and communication technologies for sustainability. Environ. Dev. Sustain. 2008, 10, 291-309. [CrossRef]

117. Kigenyi, J.; Mische, S.M.; Porter, D.M.; Rappoport, J.Z.; Vinard, A. Preparing for the Unprecedented: The Association of Biomolecular Resource Facilities (ABRF) Community Coronavirus Disease 2019 (COVID-19) Pandemic Response Part 1: Efforts to Sustainably Ramp Down Core Facility Activities. J. Biomol. Tech. JBT 2020, 31, 119. [CrossRef]

118. Lee, S.-H.; Shin, Y.; Baek, S.I. Task characteristics and work engagement: Exploring effects of role ambiguity and ICT presenteeism. Sustainability 2017, 9, 1855. [CrossRef]

119. Middleton, C. Can broadband support environmental sustainability? An exploration of claims at the household level. Telecommun. J. Aust. 2007, 59, 10.11-10.14.

120. Hassan, M.; Jincai, C.; Iftekhar, A.; Cui, X. Future of the Internet of Things Emerging with Blockchain and Smart Contracts. Future 2020, 11. [CrossRef]

121. Tokarchuk, O.; Gabriele, R.; Neglia, G. Teleworking during the Covid-19 Crisis in Italy: Evidence and Tentative Interpretations. Sustainability 2021, 13, 2147. [CrossRef]

122. Baker, E.; Avery, G.C.; Crawford, J. Home alone: The role of technology in telecommuting. Inf. Resour. Manag. J. 2006, 19, 1-22. [CrossRef]

123. Bezemer, D.J. Seize the day: Opportunities and costs in the COVID-19 crisis. Glob. Sustain. 2021, 4, e10. [CrossRef]

124. Andrade, R.O.; Ortiz-Garcés, I.; Cazares, M. Cybersecurity attacks on Smart Home during Covid-19 pandemic. In Proceedings of the 2020 Fourth World Conference on Smart Trends in Systems, Security and Sustainability (WorldS4), Online, 27-28 July 2020; pp. 398-404.

125. Bouguerra, A.; Gölgeci, I.; Gligor, D.M.; Tatoglu, E. How do agile organizations contribute to environmental collaboration? Evidence from MNEs in Turkey. J. Int. Manag. 2021, 27, 100711. [CrossRef]

126. Ehlers, J. Socialness in the Recruiting of Software Engineers. In Proceedings of the CF '15: Proceedings of the 12th ACM International Conference on Computing Frontiers, Ischia, Italy, 18-21 May 2015; Association for Computing Machinery: New York, NY, USA, 2015.

127. Heupel, T. Implementing standard costing with an aim to guiding behaviour in sustainability orientated organisa. In Sustainability Accounting and Reporting; Springer: Berlin/Heidelberg, Germany, 2006; pp. 153-180.

128. Rubio-Andrés, M.; Gutiérrez-Broncano, S.; Varona-Castillo, L. Self-managing teams in Small and Medium Enterprises (SME). In Effective Human Resources Management in Small and Medium Enterprises: Global Perspectives; IGI Global: Hershey, PA, USA, 2013; pp. 280-300.

129. Seegert, S.; Chapman, B.; Bork, K.; Runkle, K.; Eickhoff, C. Trauma Data Quality Improvement: One Center's Experience With Telecommuting and Paperless Data Management. J. Trauma Nurs. Off. J. Soc. Trauma Nurses 2020, 27, 170-176. [CrossRef] [PubMed]

130. Seitz, C.; Kleinschmidt, T. Awakening processes to life. ZWF Z. Fuer Wirtsch. Fabr. 2008, 103, 246-248. [CrossRef]

131. Vargas, A.V.; Osma, J.I.P. Proposal for implementing a telecommuting model. RISTI-Rev. Iber. Sist. Tecnol. Inf. 2013, 17-31. [CrossRef]

132. Nwokocha, I.; Iheriohanma, E. Emerging trends in employee retention strategies in a globalizing economy: Nigeria in focus. Asian Soc. Sci. 2012, 8, 198-207. [CrossRef]

133. Moos, M.; Skaburskis, A. The probability of single-family dwelling occupancy: Comparing home workers and commuters in Canadian Cities. J. Plan. Educ. Res. 2008, 27, 319-340. [CrossRef]

134. Hensher, D.A.; Wei, E.; Beck, M.; Balbontin, C. The impact of COVID-19 on cost outlays for car and public transport commutingThe case of the Greater Sydney Metropolitan Area after three months of restrictions. Transp. Policy 2021, 101, 71-80. [CrossRef]

135. Lachapelle, U.; Tanguay, G.A.; Neumark-Gaudet, L. Telecommuting and sustainable travel: Reduction of overall travel time, increases in non-motorised travel and congestion relief? Urban Stud. 2018, 55, 2226-2244. [CrossRef]

136. Rietveld, P. Telework and the transition to lower energy use in transport: On the relevance of rebound effects. Environ. Innov. Soc. Transit. 2011, 1, 146-151. [CrossRef] 
137. Campisi, T.; Basbas, S.; Skoufas, A.; Akgün, N.; Ticali, D.; Tesoriere, G. The impact of covid-19 pandemic on the resilience of sustainable mobility in sicily. Sustainability 2020, 12, 1-25. [CrossRef]

138. Guzman, L.A.; Arellana, J.; Alvarez, V. Confronting congestion in urban areas: Developing Sustainable Mobility Plans for public and private organizations in Bogotá. Transp. Res. Part A Policy Pract. 2020, 134, 321-335. [CrossRef]

139. Hakovirta, M.; Denuwara, N. How COVID-19 redefines the concept of sustainability. Sustainability 2020, 12, 3727. [CrossRef]

140. Bohman, H.; Ryan, J.; Stjernborg, V.; Nilsson, D. A study of changes in everyday mobility during the Covid-19 pandemic: As perceived by people living in Malmö, Sweden. Transp. Policy 2021, 106, 109-119. [CrossRef]

141. Brewer, A.M.; Hensher, D.A. Distributed work and travel behaviour: The dynamics of interactive agency choices between employers and employees. Transportation 2000, 27, 117-148. [CrossRef]

142. Caulfield, B. Does it pay to work from home? Examining the factors influencing working from home in the Greater Dublin Area. Case Stud. Transp. Policy 2015, 3, 206-214. [CrossRef]

143. Heinonen, S.; Kuosa, T. Ecological realities of telework in four different futures: Living, working and travelling in new knowledgeintensive communities. Prog. Ind. Ecol. 2005, 2, 329-357. [CrossRef]

144. Vanoutrivespi, T.; van Malderen, L.; Jourquinspi, B.; Thomasspi, I.; Verhetselspi, A.; Witlox, F. Mobility management measures by employers overview and exploratory analysis for Belgium. Eur. J. Transp. Infrastruct. Res. 2010, 10, 121-141. [CrossRef]

145. Wang, K.; Ozbilen, B. Synergistic and threshold effects of telework and residential location choice on travel time allocation. Sustain. Cities Soc. 2020, 63, 102468. [CrossRef] [PubMed]

146. Andrey, J.C.; Burns, K.R.; Doherty, S.T. Toward sustainable trasportation: Exploring transportation decision making in teleworking households in a mid-sized Canadian city. Can. J. Urban Res. 2004, 13, 257-277.

147. Kenworthy, J.R. The eco-city: Ten key transport and planning dimensions for sustainable city development. Environ. Urban. 2006, 18, 67-85. [CrossRef]

148. Batty, M. The size, scale, and shape of cities. Science 2008, 319, 769-771. [CrossRef]

149. Camagni, R.; Gibelli, M.C.; Rigamonti, P. Urban mobility and urban form: The social and environmental costs of different patterns of urban expansion. Ecol. Econ. 2002, 40, 199-216. [CrossRef]

150. Newman, P. Density, the sustainability multiplier: Some myths and truths with application to perth, Australia. Sustainability 2014, 6, 6467-6487. [CrossRef]

151. Newman, P. Rediscovering compact cities for sustainability. In Elgar Companion to Sustainable Cities: Strategies, Methods and Outlook; Edward Elgar Publishing: Cheltenham, UK, 2014; pp. 15-31.

152. Hopkins, J.L.; McKay, J. Investigating 'anywhere working' as a mechanism for alleviating traffic congestion in smart cities. Technol. Forecast. Soc. Chang. 2019, 142, 258-272. [CrossRef]

153. Neuman, M. The compact city fallacy. J. Plan. Educ. Res. 2005, 25, 11-26. [CrossRef]

154. Wang, S.; Yu, D.; Ma, X.; Xing, X. Analyzing urban traffic demand distribution and the correlation between traffic flow and the built environment based on detector data and POIs. Eur. Transp. Res. Rev. 2018, 10, 50. [CrossRef]

155. Delanoe, A.; Chavalarias, D.; Anglade, A. Dematerialization and the environment: A text-mining landscape on academic, blog and press publications. In Proceedings of the ICT for Sustainability 2014, ICT4S 2014, Stockholm, Swiss, 24-27 August 2014; pp. 199-207.

156. Hynes, M. The practices of technology: Putting society and technology in their rightful place. Int. J. Technol. Knowl. Soc. 2012, 8, 27-44. [CrossRef]

157. Asano, S.; Yoneda, S. Standard and environmental considerations toward sustainable infrastructure. In Proceedings of the 6th International Conference on Standardization and Innovation in Information Technology, SIIT 2009, Al-Ain, United Arab Emirates, 10-17 December 2009; pp. 165-170.

158. Ishibashi, K.; Furuta, H.; Nakatsu, K. Bridge Maintenance Scheduling in Consideration of Resilience Against Natural Disasters. Front. Built Environ. 2020, 6, 179. [CrossRef]

159. Mitomo, H. Telework and telecommuting in Japan: Sustainability and macroeconomic perspectives. In Convergence of Telecommunications and Broadcasting in Japan, United Kingdom and Germany: Technological Change, Public Policy and Market Structure; Routledge: London, UK, 2013; pp. 119-130.

160. Tintin, R.A.; Vela, M.; Anzules, V.; Escobar, V. Smart cities and telecommuting in Ecuador. In Proceedings of the 2015 2nd International Conference on eDemocracy and eGovernment, ICEDEG 2015, Quito, Ecuador, 8-10 April 2015; pp. 49-53.

161. Gao, K.; Shao, M.; Sun, L. Roles of psychological resistance to change factors and heterogeneity in car stickiness and transit loyalty in mode shift behavior: A hybrid choice approach. Sustainability 2019, 11, 4813. [CrossRef]

162. Kylili, A.; Afxentiou, N.; Georgiou, L.; Panteli, C.; Morsink-Georgalli, P.Z.; Panayidou, A.; Papouis, C.; Fokaides, P.A. The role of Remote Working in smart cities: Lessons learnt from COVID-19 pandemic. Energy Sources Part A Recovery Util. Environ. Eff. 2020, 1-16. [CrossRef]

163. Marian, S.; Bogdan, G.M. Cloud-working or telework through cloud computing-Another step towards cloudsourcing. In Proceedings of the 28th International Business Information Management Association Conference-Vision 2020: Innovation Management, Development Sustainability, and Competitive Economic Growth, Seville, Spain, 9-10 November 2016; pp. 39663973.

164. Brooks, R.M.; Cetin, M.; Kavuturu, J. Sustainability perspectives of graduate students on transportation systems and management. In Proceedings of the ASEE Annual Conference and Exposition, Conference Proceedings, Atlanta, GA, USA, $23-26$ June 2013. 
165. Lüdtke, D.U.; Luetkemeier, R.; Schneemann, M.; Liehr, S. Increase in Daily Household Water Demand during the First Wave of the Covid-19 Pandemic in Germany. Water 2021, 13, 260. [CrossRef]

166. Alda-Vidal, C.; Smith, R.; Lawson, R.; Browne, A.L. Understanding Changes in Domestic Water Consumption Associated with COVID-19 in England and Wales. AR1380; Artesia: Manchester, UK, 2020.

167. Hiselius, L.W.; Arnfalk, P. When the impossible becomes possible: COVID-19's impact on work and travel patterns in Swedish public agencies. Eur. Transp. Res. Rev. 2021, 13, 17. [CrossRef]

168. van Lier, T.; de Witte, A.; Macharis, C. How worthwhile is teleworking from a sustainable mobility perspective? The case of Brussels Capital region. Eur. J. Transp. Infrastruct. Res. 2014, 14, 244-267. [CrossRef]

169. Zhu, P.; Mason, S.G. The impact of telecommuting on personal vehicle usage and environmental sustainability. Int. J. Environ. Sci. Technol. 2014, 11, 2185-2200. [CrossRef]

170. O'Brien, W.; Yazdani Aliabadi, F. Does telecommuting save energy? A critical review of quantitative studies and their research methods. Energy Build. 2020, 225, 110298. [CrossRef] [PubMed]

171. Alonso, A.; Monzón, A.; Wang, Y. Modelling Land Use and Transport Policies to Measure Their Contribution to Urban Challenges: The Case of Madrid. Sustainability 2017, 9, 378. [CrossRef]

172. Vita, G.; Lundström, J.R.; Hertwich, E.G.; Quist, J.; Ivanova, D.; Stadler, K.; Wood, R. The Environmental Impact of Green Consumption and Sufficiency Lifestyles Scenarios in Europe: Connecting Local Sustainability Visions to Global Consequences. Ecol. Econ. 2019, 164, 106322. [CrossRef]

173. Vishwanathan, S.S.; Garg, A.; Tiwari, V.; Shukla, P.R. India in $2{ }^{\circ} \mathrm{C}$ and well below $2{ }^{\circ} \mathrm{C}$ worlds: Opportunities and challenges. Carbon Manag. 2018, 9, 459-479. [CrossRef]

174. Krarti, M.; Aldubyan, M. Review analysis of COVID-19 impact on electricity demand for residential buildings. Renew. Sustain. Energy Rev. 2021, 143, 110888. [CrossRef]

175. Kim, Y.-S.; Srebric, J. Impact of occupancy rates on the building electricity consumption in commercial buildings. Energy Build. 2017, 138, 591-600. [CrossRef]

176. Hu, H.; Jenks, G.; Huang, Y.; Milencovic, M.; Hanebutte, U. Information and communications technology based solutions in achieving building energy efficiency. In Proceedings of the 2013 1st IEEE Conference on Technologies for Sustainability (SusTech 2013), Portland, OR, USA, 1-4 August 2013; pp. 49-54.

177. Williams, E.D. Assessing the potential of telecommuting as an energy savings technology in Japan. In Proceedings of the IEEE International Symposium on Electronics and the Environment, Boston, MA, USA, 19-22 May 2003.

178. Weber, T.; Stich-Kreitner, V. The health circle for the cleaning service. Arb. Soz. Umweltmed. 2002, 37, 606-614.

179. Weisner, K.; Knittel, M.; Jaitner, T.; Deuse, J. Increasing flexibility of employees in production processes using the differential learning approach-Adaptation and validation of motor learning theories. Adv. Intell. Syst. Comput. 2019, 785, $216-225$. [CrossRef]

180. Wilson, L.A.; Rogers Van Katwyk, S.; Fafard, P.; Viens, A.M.; Hoffman, S.J. Lessons learned from COVID-19 for the post-antibiotic future. Glob. Health 2020, 16, 94. [CrossRef] [PubMed]

181. Korochentseva, A.; Terekhin, V. Teachers' Ideas about their Appearance and Features of Non-Verbal Communication with Pupils during the Distance Learning. In Proceedings of the E3S Web of Conferences, Chelyabinsk, Russia, 17-19 February 2021.

182. Day, L.G.; Cantera, P.; Bertoldi, F.; Docampo, A.; Bustos, B.; Monczor, J. DataGMA: Data-driven culture creation in shale field operations. In Proceedings of the SPE Annual Technical Conference and Exhibition, Calgary, AB, Canada, 30 September-1 June 2019.

183. Kaspary, M.C. Complex thought and systems thinking connecting group process and team management: New lenses for social transformation at work environment. In Proceedings of the 57th Annual Meeting of the International Society for the Systems Sciences, ISSS 2013: Curating the Conditions for a Thrivable Planet, Hai Phong City, Vietnam, 14-19 July 2013 ; pp. $413-431$.

184. Puyt, R.; Lie, F.B.; De Graaf, F.J.; Wilderom, C.P. Origins of SWOT Analysis. In Proceedings of the Academy of Management Proceedings, Virtual, Online, 7-11 August 2020; p. 17416.

185. Gurl, E. SWOT Analysis: A Theoretical Review; Willey: Hoboken, NJ, USA, 2017.

186. Leigh, D. SWOT Analysis. Handbook of Improving Performance in the Workplace; Willey: Hoboken, NJ, USA, 2009; Volumes 1-3, pp. 115-140.

187. UNDP. Human Development Report 2020: The Next Frontier Human Development and the Anthropocene; United Nations Development Programme: New York, NY, USA, 2020.

188. Global Workplace Analytics. Advantages of Agile Work Strategies For Companies. Available online: https: / globalworkplaceanalytics. com/resources / costs-benefits (accessed on 3 May 2021).

189. WHO. Health Topics: Air Pollution. Available online: https://www.who.int/health-topics/air-pollution\#tab=tab_1 (accessed on 3 May 2021).

190. Bornemann, B.; Weiland, S. The un 2030 agenda and the quest for policy integration: A literature review. Politics Gov. 2021, 9 , 96-107. [CrossRef]

191. Williams, O.A. Drugs, Alcohol, and Narcissism: How Working from Home Hurt the Wealthy. Available online: https: //www.forbes.com/sites / oliverwilliams1/2020/09/27/drugs-alcohol-and-narcissism-how-working-from-home-hurt-thewealthy /?sh=456fe24049a1 (accessed on 15 July 2021). 
192. AmericanAddictionCentres alcohol.org. Drinking Alcohol When Working from Home. Available online: https://www.alcohol. org/guides/work-from-home-drinking/ (accessed on 13 August 2021).

193. Abujledan, H.M.; Akram, F.; Abdullah, I.A.; Mallah, A.S.; Hashim, H.T. The Shadow Pandemic: An insight on the rise in domestic abuse in Southeast Asian countries due to the imposed lockdown. Ethics Med. Public Health 2021, 18, 100687. [CrossRef]

194. Bhavsar, V.; Kirkpatrick, K.; Calcia, M.; Howard, L.M. Lockdown, domestic abuse perpetration, and mental health care: Gaps in training, research, and policy. Lancet Psychiatry 2021, 8, 172-174. [CrossRef]

195. Suraj, S.; Tendolkar, V.D.; Sarode, R. Domestic violence: A silent panendemic on the rise during COVID-19. Indian J. Forensic Med. Toxicol. 2020, 14, 6461-6463. [CrossRef]

196. Warburton, E.; Raniolo, G. Domestic Abuse during COVID-19: What about the boys? Psychiatry Res. 2020, 291, 113155. [CrossRef]

197. Weller, S.J.; Tippetts, D.; Weston, D.; Aldridge, R.W.; Ashby, J. Increase in reported domestic abuse in Integrated Sexual Health (ISH) services in London and Surrey during COVID-19 'lockdown': Successful application of national guidance on routine enquiry during rapid transition to remote telephone consultation (telemedicine). Sex. Transm. Infect. 2021, 97, 245-246. [CrossRef] [PubMed]

198. Webb, R.; Bai, X.; Smith, M.S.; Costanza, R.; Griggs, D.; Moglia, M.; Neuman, M.; Newman, P.; Newton, P.; Norman, B.; et al. Sustainable urban systems: Co-design and framing for transformation. Ambio 2017, 47, 1-21. [CrossRef] [PubMed] 